\title{
Karaokê da Câmara dos Deputados: o uso do microfone na atividade parlamentar
}

$\overline{\text { Davi Moreira }^{1} \text { (i) }}$

O artigo apresenta a tese de que a atividade parlamentar no âmbito da Câmara dos Deputados não se reduz ao processo decisório. Ele responde à seguinte questão: há indícios suficientes para afirmar que a frequência de comunicação parlamentar no âmbito da Câmara dos Deputados é governada pela relação governo-oposição, assim como constatado em sua atuação no processo decisório? Para respondê-la, foi realizada a análise da frequência de discursos proferidos por mais de 2 mil oradores diferentes ao longo de mais de 15 anos. Com evidências robustas sobre a frequência dos discursos proferidos, verifica-se que essa atividade não é governada pela relação governo-oposição. Os resultados apresentam a influência de outras variáveis sobre a atuação parlamentar.

Palavras-chave: comportamento político; discurso político; atividade parlamentar; governo-oposição; Câmara dos Deputados

\section{Introdução}

A análise da atividade parlamentar com o objetivo de compreender como e por que o representante político se comporta de determinada maneira envolve a mobilização de diferentes objetos de pesquisa e variáveis para sua explicação e descrição. Como ocorreu na literatura americana (Clinton, Jackman e Rivers, 2004; Poole e Rosenthal, 1991), a disponibilidade de dados e a facilidade de modelagem, cruzamentos, descrição e inferência fizeram com que a agenda de estudos sobre o comportamento parlamentar no Legislativo brasileiro se desenvolvesse com foco primordial sobre o processo decisório, especialmente no que tange às votações nominais e à produção legislativa como objetos de pesquisa (Freitas, 2010, 2013; Izumi, 2013; Limongi e Figueiredo, 1998, 2005; Medeiros, Freitas e Izumi, 2013; Moreira, 2011; Pereira e Mueller, 2000, 2002, 2003; Ricci, 2003, 2006; Zucco Jr., 2009; Zucco Jr. e Lauderdale, 2011).

No caso das votações nominais, sua relevância para a ciência política brasileira é tamanha que se tornou objeto básico para o entendimento de um leque de questões relacionadas ao funcionamento do presidencialismo de coalizão e à governabilidade do

\footnotetext{
${ }^{1}$ Universidade Federal de Pernambuco, Departamento de Filosofia e Ciências Humanas. Recife (PE), Brasil. E-mail: <davi.moreira@gmail.com>.
} 
sistema político nacional. No caso da produção legislativa, mesmo que de forma esparsa, o conteúdo legislativo aprovado foi foco de análises quanto a seu impacto territorial, sendo sua elaboração objeto de pesquisas sobre a participação legislativa e a possível interferência de grupos de interesse.

Ambos os objetos de análise fizeram do processo decisório no Congresso Nacional (CN) o principal eixo de pesquisas para o entendimento da atividade parlamentar, sua representação e seu papel sobre a governabilidade. Para tanto, dois grandes conjuntos de variáveis foram mobilizados com o objetivo de descrever, predizer e explicar a atuação dos representantes (Figura 1): i) variáveis oriundas da arena legislativa e ii) variáveis com origem na arena eleitoral. Atualmente, o conhecimento produzido a respeito do padrão de votação e produção legislativa indica que este é guiado pela relação governo-oposição, seguindo os pressupostos da tese do presidencialismo de coalizão (Abranches, 1988; Arretche, 2007; Figueiredo e Limongi, 2002, 1999; Limongi e Figueiredo, 1998; Zucco Jr., 2009).

\section{Figura 1}

\section{Esquema de análise da atividade parlamentar}

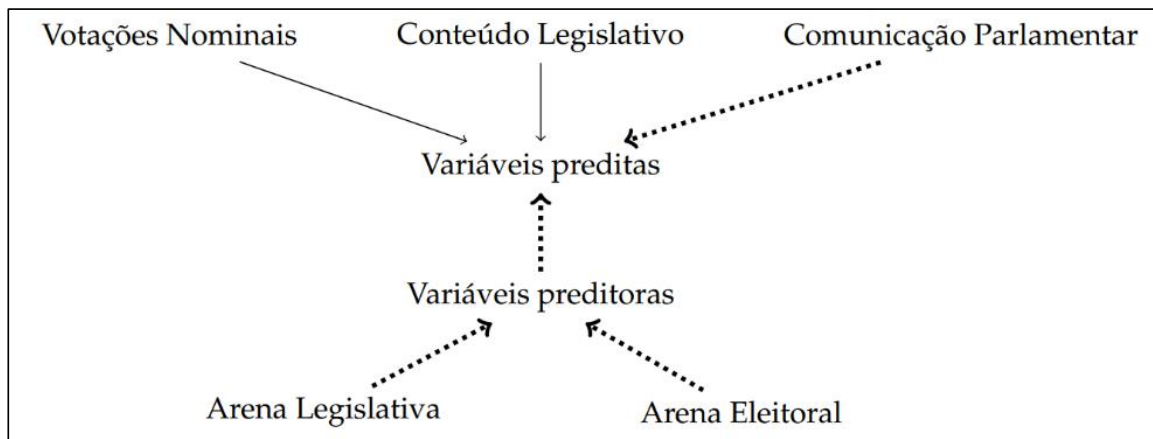

Fonte: Elaboração própria a partir da revisão da literatura.

Descrição: A Figura 1 apresenta de forma esquemática a estrutura básica de análise da atividade parlamentar na ciência política. De baixo para cima, as arenas legislativa e eleitoral proveem variáveis preditoras com o objetivo de descrever as variáveis preditas que, de cima para baixo, são fruto de diferentes dimensões da atuação parlamentar, no caso: votações nominais, produção de conteúdo legislativo e comunicação parlamentar. Em destaque, através de flechas pontilhadas, encontra-se localizada a estrutura básica deste artigo.

Apesar da robustez que as análises a respeito do processo decisório ganharam na agenda brasileira de estudos legislativos, pouco se sabe sobre os incentivos que a arena legislativa e a arena eleitoral produzem em relação a outras atividades que os parlamentares desenvolvem no âmbito do Congresso Nacional. Uma dessas atividades é a comunicação parlamentar através de momentos institucionais previstos nos regimentos internos das duas Casas legislativas.

De forma mais frequente do que a elaboração e a aprovação de leis, por exemplo, cotidianamente deputados federais acessam a tribuna da Câmara dos 
Deputados (CD) para proferir explanações a respeito de sua atividade, sua posição em relação a algum tema específico, homenagear alguma personalidade ou ente querido, responder a indagações e assim acessar colegas, eleitores e correligionários ${ }^{2}$. Mesmo com tamanha frequência, a ciência política brasileira pouco conhece a atividade de comunicação parlamentar no âmbito do Congresso Nacional. Não se sabe o volume de falas, o padrão de uso dos momentos institucionais previstos para comunicação e muito menos o conteúdo expresso nesses discursos. Dado esse fato, menor ainda é o conhecimento dos padrões que regem essa atividade parlamentar e os efeitos das principais variáveis que orientam as pesquisas sobre esse comportamento congressista ${ }^{3}$.

O presente artigo visa preencher essa lacuna e apresenta resultados para o princípio de uma profícua agenda de pesquisa no campo dos estudos legislativos e comportamento político no Brasil ao analisar a frequência de discursos parlamentares proferidos no Pequeno Expediente da Câmara dos Deputados de 1999 a 2014, ao longo das legislaturas 51, 52, 53 e 54. Valendo-se da rica literatura que analisa a votação nominal (Limongi e Figueiredo, 1998, 2005; Pereira e Mueller, 2000, 2002, 2003; Zucco Jr., 2009; Zucco Jr. e Lauderdale, 2011) e da produção do conteúdo legislativo aprovado (Freitas, 2010, 2013; Moreira, 2011; Ricci, 2003, 2006), este artigo visa responder à seguinte questão: há indícios suficientes para afirmar que a comunicação parlamentar no âmbito da Câmara dos Deputados é governada pela relação governo-oposição, assim como constatado em sua atuação no processo decisório?

Conforme destacado na Figura 1, através de estudo exploratório e da mobilização de variáveis oriundas tanto da arena legislativa quanto da arena eleitoral, este artigo apresenta conclusões a respeito dos determinantes da frequência de discursos realizados e das estratégias de comunicação adotadas pelos deputados federais brasileiros. Neste artigo, enfatiza-se a importância da análise dessa dimensão da atividade parlamentar sobre o funcionamento do sistema político brasileiro, sua governança e representatividade com o objetivo de contribuir com uma nova e profícua agenda de pesquisa.

$\mathrm{Na}$ próxima seção, "A atividade parlamentar: visões da literatura e o caso brasileiro", apresento o desenvolvimento da literatura da ciência política sobre o comportamento parlamentar e o caso brasileiro. Para facilitar a apresentação, com base na estrutura proposta na Figura 1 são enfatizadas pesquisas cujo escopo de análise se debruça sobre três grandes linhas de abordagem: o voto nominal, o conteúdo legislativo e a comunicação parlamentar.

Amparada pelas regras que organizam os trabalhos na Câmara dos Deputados, porém distante dos regulamentos que regem os processos decisórios, a comunicação

\footnotetext{
2 Apenas por curiosidade, somadas as legislaturas 51, 52, 53 e 54 (de 1999 a 2014), foram realizadas 1.927 votações nominais na CD. Nesse mesmo período, somente no Pequeno Expediente, foram realizados mais de 127 mil pronunciamentos.

${ }^{3}$ A única referência que se destaca nesse quadro de escassez é o trabalho de Miguel e Feitosa (2009).
} 
parlamentar ocorre em momentos institucionais de fala previstos regimentalmente. $\mathrm{Na}$ seção seguinte, "A comunicação parlamentar na Câmara dos Deputados", esses momentos são descritos e é justificada a escolha do Pequeno Expediente como foco deste artigo. Em seguida, em "O uso da fala na Câmara dos Deputados", é apresentada a análise sobre a frequência de uso desses momentos institucionais pelos deputados federais entre 1999 e 2014. Em especial, é nesta seção que a questão de pesquisa deste artigo é respondida. Por fim, são apresentadas as conclusões.

\section{A atividade parlamentar: visões da literatura e o caso brasileiro}

\section{O voto nominal}

O trabalho seminal de Poole e Rosenthal (1991) é considerado o início de uma frutífera agenda de pesquisa com foco no voto nominal para análise do comportamento parlamentar. Avanços metodológicos desenvolvidos por esses pesquisadores aprimoraram esse campo de análise através de uma medida de posicionamento (ideal points) calculada a partir do registro de votações nominais (Clinton, Jackman e Rivers, 2004; Poole e Rosenthal, 1991). O efeito de seu resultado é tamanho que, no caso da política americana, sugere-se que uma única dimensão de conflito caracterizaria a competição ideológica existente no Congresso, pois seria possível identificá-la através do posicionamento do ponto ideal de cada congressista nessa dimensão (Poole e Rosenthal, 1991).

As pesquisas da extensa e robusta agenda resultante da análise dos pontos ideais obtidos pelos registros das votações nominais avançaram a ponto de envolver e comparar as preferências políticas de cada legislador em relação a outras fontes de informação, oriundas tanto da arena eleitoral como da arena legislativa. No caso da primeira, medidas obtidas a partir de surveys e do financiamento de campanha são comparadas ao ponto ideal estimado em votações nominais com o objetivo de auferir sua proximidade e a compatibilidade entre o comportamento parlamentar, a opinião de eleitores e o posicionamento de financiadores de campanhas (Ansolabehere e Jones, 2010; Bonica, 2014). Em relação à arena legislativa, aplicada a diferentes sistemas políticos, foi possível identificar que as conclusões obtidas para o caso americano não se ajustam necessariamente a estruturas institucionais distintas como, por exemplo, o caso brasileiro (Zucco Jr., 2009).

No Brasil, o estado atual da literatura sobre o voto nominal apresenta que este é guiado pela relação governo e oposição, segundo os pressupostos da tese do presidencialismo de coalizão (Abranches, 1988). Essa conclusão é fruto de um longo debate acadêmico que refutou diferentes teses sobre o comportamento individual dos legisladores brasileiros. Duas são as principais teses superadas nesse debate: uma de essência regional e outra de fundo ideológico. 
No primeiro caso, o voto parlamentar defenderia os interesses vinculados à unidade federativa (UF) que o legislador representa (Ames, 1995a, 2002; Mainwaring, 1991, 1999; Pereira e Mueller, 2002). Com base na tese do voto pessoal (Cain, Ferejohn e Fiorina, 1990), o sistema eleitoral proporcional de lista aberta brasileiro determinaria o comportamento legislativo do representante. Nesse modelo, "a atuação dos partidos políticos na arena legislativa seria, basicamente, uma consequência funcional da necessidade de se vencer eleições" (Pereira e Mueller, 2003, p. 736).

Assumindo que a arena decisória está à mercê de incentivos proporcionados pelo sistema eleitoral, diante de regras eleitorais que favorecem a relação direta entre político e eleitor, políticos sensatos não perderiam a oportunidade de maximizar a distribuição de benefícios a seus redutos eleitorais com o objetivo de obter os créditos por concessões realizadas (credit claiming) (Mayhew, 1974, p. 54) e aumentar as chances de sua manutenção no poder. Nessa formatação institucional, no Poder Legislativo prepondera o caráter distributivista da atuação parlamentar (Shepsle e Weingast, 1995). Nela, o Poder Executivo estaria à mercê dos interesses individuais dos parlamentares e seria obrigado a com eles negociar individualmente para obter maioria para suas propostas.

Os trabalhos que refutam referida tese destacam que a composição da maioria legislativa através da distribuição de pastas ministeriais, somada às regras que regem o processo decisório e organizam os trabalhos do Congresso Nacional, atribui poder de agenda ao presidente da República e às lideranças partidárias, criando incentivos para que os parlamentares da base se comportem de forma coletiva, seguindo a orientação de suas legendas. Logo, mostram que, se o sistema eleitoral brasileiro gera incentivos particularistas, para que os parlamentares obtenham sucesso em promover sua imagem perante suas bases, estes devem seguir os incentivos partidários presentes na arena legislativa (Arretche, 2007; Figueiredo e Limongi, 2002, 1999; Limongi e Figueiredo, 1998; Zucco Jr., 2009). Para essa corrente, no Legislativo nacional prepondera uma organização partidária que tem direto reflexo sobre a dinâmica e o resultado do processo legislativo (Cox e McCubbins, 2007).

No segundo caso, o voto parlamentar seria fruto do perfil ideológico do representante (Leoni, 2002). Ao estimar pontos ideais a partir dos registros de votações nominais, Leoni (2002) encontra forte correlação entre ideologia e posicionamento partidário. Ele conclui que o espectro ideológico seria suficiente para predizer corretamente $85 \%$ dos votos nominais e que, portanto, o comportamento do deputado federal brasileiro seria semelhante ao perfil identificado no caso americano (Poole e Rosenthal, 1991).

Com essa constatação, bastou a alternância de partidos oposicionistas no poder do Executivo Federal para que a tese da expressão ideológica pelo voto fosse derrubada (Zucco Jr., 2009). Através de uma medida ideológica exógena à atividade legislativa, Zucco Jr. (2009) apresenta que a análise de votações nominais não é um bom método para captar a ideologia do parlamentar brasileiro. Seu trabalho conclui que o resultado 
obtido na estimação de ponto ideal do parlamentar por meio da votação nominal é fruto de seu posicionamento estratégico perante seu partido e o Poder Executivo. A concentração de recursos e a competência de sua execução no Poder Executivo criam incentivos para que os parlamentares sigam o posicionamento de suas legendas partidárias e, portanto, seu voto reflita a relação entre governo e oposição.

Superadas as teses apresentadas para o caso brasileiro, a conclusão atual a respeito do comportamento parlamentar na expressão do voto nominal está amparada no seu posicionamento diante da legenda partidária e na relação entre governo e oposição. O trabalho de Zucco Jr. (2009) mostrou que ainda há muito a se conhecer sobre o perfil do parlamentar brasileiro e que a expressão do voto nominal não permite esse avanço para além do objetivo de analisar questões referentes ao processo de aprovação legislativa.

Apesar de tamanha preponderância, a análise da atividade parlamentar através das votações nominais não se configurou em exclusividade para seu entendimento. Com a mobilização de variáveis oriundas tanto da arena legislativa quanto da arena eleitoral foram identificadas limitações e restrições analíticas desse objeto para uma compreensão mais fidedigna da atividade congressista. Ainda sob o escopo do processo decisório, resta saber quais conclusões a literatura apresenta a respeito da produção do conteúdo legislativo. É sobre essa dimensão da atuação parlamentar que a próxima subseção se desenvolve.

\section{O conteúdo legislativo}

Os clássicos trabalhos de Mayhew (1974), Fiorina (1977) e Fenno (1973) já destacavam que os modelos de explicação do comportamento parlamentar com base no voto nominal renegam um amplo leque de atividades desenvolvidas pelo representante político. A relevância teórica desses trabalhos é indiscutível e permitiu a evolução de uma agenda de pesquisas a respeito da atividade parlamentar que não se restringe à sua atuação sobre o processo decisório.

Os estudos que analisam a produção de políticas públicas através da elaboração de conteúdo legislativo no Brasil, por exemplo, destacam que a conexão eleitoral vinculada à tese do voto pessoal determinaria o comportamento legislativo do representante (Cain, Ferejohn e Fiorina, 1990; Downs, 1957; Mayhew, 1974). Nesse two-arena model (Mayhew, 1974), a arena decisória estaria à mercê de incentivos proporcionados pelo sistema eleitoral e, diante de regras eleitorais que favorecessem a relação direta entre parlamentar e eleitor, políticos sensatos não perderiam a oportunidade de maximizar a distribuição de benefícios particulares a seus redutos eleitorais com o objetivo de obter os créditos por concessões realizadas (credit claiming) (Mayhew, 1974; Shepsle e Weingast, 1995) e aumentar as chances de sua manutenção 
no poder. Para ter sucesso nessa estratégia, precisam ter influência direta sobre o conteúdo legislativo aprovado.

Independentemente da amplitude dos benefícios gerados pela lógica da literatura da conexão eleitoral, o fato é que, quanto mais incentivos pessoais o sistema eleitoral proporcionar, mais os políticos canalizam, de forma individual, benefícios a seu eleitorado. Contudo, essa agenda de pesquisa evoluiu no sentido de agregar outros atores (e.g., partidos e grupos de interesse) à produção de conteúdo legislativo (Ricci, 2006). Três seriam as principais razões para a inserção de outros atores nas análises que buscam explicar o comportamento político dos representantes na formulação de políticas públicas: a capacidade de organização desses atores, a assimetria de informação presente na sociedade como um todo e as regras que regulam o processo decisório.

Olson (1971) destaca que grupos pequenos (em número de membros) têm maior facilidade em superar o free-rider problem e de se organizar de forma eficiente para pressionar autoridades políticas com relação a seus interesses ${ }^{4}$. Pressionados, parlamentares tendem a beneficiar os grupos interessados com o objetivo de aumentar sua competitividade em eleições futuras através de seu apoio e financiamento (Baron, 1994; Grossman e Helpman, 1996; Lohmann, 1998; Potters e Sloof, 1996; Smith, 1995).

Sem desconsiderar a tese desenvolvida por Olson (1971), Lohmann (2003) argumenta que não é apenas a maior capacidade de organização que possibilita aos grupos de interesse ganhos políticos em relação à população em geral. O que favorece a atuação política de representantes em favor de grupos de interesse é o impacto político da assimetria de informação existente entre pequenos grupos e a população como um todo. Como Downs (1957) apresenta, a lógica de funcionamento das democracias representativas impõe limites à ampla informação. Cada eleitor pode ser considerado um interesse organizado e especializado em algumas áreas. No entanto, em relação à grande maioria dos temas sobre os quais a atividade política se debruça, o eleitorado tem apenas uma vaga ideia do impacto gerado pelas decisões que são constantemente tomadas. Assim, somente em relação às dimensões sociais nas quais o eleitor é especializado é possível a ele auferir o que os políticos têm feito a favor ou contra ele (Lohmann, 2003, p. 308).

Se, de um lado, a assimetria de informação e a capacidade de organização podem produzir interferência sobre o comportamento individual do parlamentar, podendo tal aspecto formatar a dinâmica dos trabalhos, a organização legislativa e, inclusive, o conteúdo legislativo (Krehbiel, 1992), de outro, a arena legislativa pode colocar restrições à atuação do representante sobre o processo decisório e, consequentemente, sobre o conteúdo legal aprovado. No caso brasileiro, por exemplo, com o objetivo de

\footnotetext{
${ }^{4} \mathrm{O}$ "problema do carona" consiste na hipótese de indivíduos não assumirem os custos de uma determinada ação e aguardarem pelos benefícios de um empreendimento através dos custos assumidos por outros.
} 
explicar a governabilidade do sistema político brasileiro, uma ampla literatura analisou a participação parlamentar na formulação do processo orçamentário nacional.

Esse debate se desenvolveu em pelo menos duas vertentes diferentes: uma que se dedica aos aspectos institucionais da relação Executivo-Legislativo e ao comportamento político sob a ótica da tese do voto pessoal; e outra que nega os pressupostos da primeira e indica que a alocação de recursos públicos federais não está atrelada a uma disputa entre os poderes e, muito menos, obedece a critérios eleitorais personalistas, uma vez que as regras do processo decisório impedem o particularismo legislativo.

A primeira vertente que analisa a alocação de recursos públicos via processo orçamentário tem como expoente o trabalho de Pereira e Mueller (2002) e argumenta que a produção legislativa brasileira está submetida a um jogo de barganha entre os poderes Executivo e Legislativo. Em virtude da separação de poderes, própria do presidencialismo, o Executivo Federal não teria como governar, pois a arena parlamentar funcionaria como um poder de veto a suas propostas (Ames, 2002). Para obter governabilidade, o Executivo atenderia a demandas políticas dos parlamentares. No caso brasileiro, um desses momentos de barganha seria o processo orçamentário, principalmente no que tange à execução das emendas individuais. Através dele, o Executivo poderia atender aos anseios de deputados e senadores e conferir a eles a decisão sobre a alocação de parte dos recursos da União em troca de apoio político em futuras votações (Ames, 1995a, 1995b, 2002; Mainwaring, 1991, 1999; Pereira e Mueller, 2002).

A segunda abordagem referente à alocação de recursos públicos via processo orçamentário critica o pressuposto de que no presidencialismo de coalizão brasileiro haja um enfrentamento direto entre os poderes Executivo e Legislativo. Seu argumento fundamental é de que não há diretamente um jogo de barganha entre os poderes, há, na verdade, uma disputa política entre situação e oposição (Figueiredo e Limongi, 1998, 1999, 2002, 2010). Expoentes dessa vertente, Figueiredo e Limongi (2002) afirmam que tratar outputs políticos do país como fruto dos conflitos existentes entre os poderes Executivo e Legislativo exclui a principal variável dessa relação, os partidos políticos (Cox e McCubbins, 2007). No que tange ao processo orçamentário, esses autores destacam que o processo decisório é centralizado e a concentração de poderes legislativos na presidência da República induz o parlamentar individual a atuar por meio dos partidos políticos para, de algum modo, obter sucesso em suas ações (Figueiredo e Limongi, 2002, p. 306).

Fora do escopo do processo orçamentário nacional, ainda não há pesquisa que tenha analisado a contribuição parlamentar na formulação de todas as leis aprovadas após a Constituição Federal de 1988. Contudo, sob objetivos distintos, dois trabalhos recentes destacam a relevante participação dos parlamentares brasileiros na formulação do conteúdo final aprovado (Freitas, 2013; Moreira, 2011). 
Com o intuito de averiguar como se comportaram os atores envolvidos no processo de formulação da política de benefícios tributários referentes à contribuição para o Programa de Integração Social (PIS), à Contribuição para o Financiamento da Seguridade Social (Cofins) e à Contribuição Sobre o Lucro Líquido (CSLL) e quais os potenciais impactos do conteúdo das leis aprovadas sobre a sociedade brasileira entre 1995 e 2010, Moreira (2011) identificou que, mesmo submetido à agenda do Poder Executivo, o Legislativo federal foi protagonista na formulação da política ao quantificar sua participação sobre o conteúdo total das leis e mostrar que a participação do Poder Legislativo foi concentrada na base que dá apoio ao governo através de postos centrais do processo legislativo, negando a tese de existência de uma conexão eleitoral baseada na atividade individual do representante político.

Por sua vez, com o objetivo de evidenciar o mecanismo fundamental pelo qual se sustenta o presidencialismo brasileiro, a coalizão, Freitas (2013) analisou uma amostra considerável de leis sem focar numa temática específica e demonstrou que o Poder Legislativo possui papel fundamental na formulação do conteúdo aprovado. Também negando a tese do comportamento individual dos parlamentares, identifica que a participação legislativa no conteúdo legal acontece através da coordenação dos partidos que compõem a coalizão governamental, em especial na figura dos relatores. Em suas palavras: "os legisladores deliberam e alteram as propostas que vêm do Executivo e suas alterações têm impacto significativo no ordenamento jurídico do país" (Freitas, 2013, p. 146). Tal constatação corrobora sua tese de que a governabilidade brasileira não se restringe ao governo do Poder Executivo após a formatação de uma maioria no Congresso Nacional com a distribuição de pastas ministeriais. De fato, trata-se de um sistema cuja governabilidade resulta de uma coalizão governamental transversal aos poderes Executivo e Legislativo.

Portanto, assim como no caso da análise das votações nominais, o comportamento parlamentar na formulação do conteúdo legislativo brasileiro é governado pelos argumentos que embasam a tese do presidencialismo de coalizão. Agrupando essas duas dimensões da atividade parlamentar (votação nominal e influência no conteúdo legislativo aprovado), sob o escopo do processo decisório, não resta dúvida de que parcela importante do funcionamento do sistema político brasileiro e da atividade desenvolvida pelos deputados federais na CD se configura de modo a respeitar a relação governo-oposição.

No esquema aqui proposto, resta agora averiguar quais conclusões podem advir da comunicação parlamentar realizada na Câmara dos Deputados. Assim como no voto nominal e na formulação do conteúdo legislativo, a relação governo-oposição orientaria essa atividade parlamentar? 


\section{A comunicação parlamentar}

Com seu uso instrumental e estratégico conhecido há milênios (Aristóteles, 2012, século IV a.C.), a comunicação é instrumento fundamental da política, desempenhando papel central nas relações de poder da sociedade e de representação nos regimes democráticos modernos (Foucault, 2005; Manin, 1997). Uma vez que a atividade do representante político se debruça sobre quaisquer aspectos da vida cotidiana e que os eleitores têm pouco incentivo e alto custo para coletar informações a respeito de sua ação (Downs, 1957; Lohmann, 2003), o eleitorado se torna praticamente um consumidor passivo de informação, produzindo problemas e oportunidades aos representantes eleitos.

Em relação aos problemas, representantes que buscam a reeleição ou sua candidatura a outros cargos eletivos podem não ter a atenção desejada por parte de seus eleitores. Essa que seria uma das principais vantagens do incumbente (Cain, Ferejohn e Fiorina, 1990) pode se tornar um enorme obstáculo em sua trajetória política, pois uma estratégia de comunicação mal adotada permite ataques oposicionistas e o desgaste de imagem perante o eleitorado até um novo pleito.

Por sua vez, as oportunidades nascem justamente desses problemas. Os representantes têm a chance de se tornar canal legítimo de informação e interpretação a respeito de sua atuação, seja através da mídia tradicional (jornais, rádio, revista, TV etc.), seja em contato direto com seu eleitor através da internet e das redes sociais. No caso do incumbente, por exemplo, há incentivo ao uso da infraestrutura institucional disponibilizada para comunicação política (Grimmer, 2010, 2013). Em combinação com as demais mídias, ela reduz custos, aumenta as vias pelas quais o representante preenche de comunicação o intervalo entre campanhas ao fornecer a seu eleitorado insumos informacionais a respeito de sua atuação (Arnold, 1990; Jacobson, 1989) e de si mesmo com o objetivo de melhorar sua reputação (Reher, 2012).

É na lacuna informacional proporcionada pela estrutura social moderna que reside a oportunidade de o representante se tornar o principal filtro de comunicação e interpretação a respeito de sua atuação política (Downs, 1957; Fenno, 1973; Grimmer, 2013; Grimmer, Westwood e Messing, 2014). O representante transforma a margem de manobra presente no espaço entre ação e comunicação num importante componente do processo de representação e atuação (Cain, Ferejohn e Fiorina, 1990; Fenno, 1973; Grimmer, 2013). Desse modo, inverte a relação principal-agente, presente em muitos modelos de representação, ao ter a chance de ditar para o eleitor (principal) qual avaliação proceder a seu respeito (agente) (Grimmer, 2013). Antecipando reações, os representantes desenvolvem presentational styles para informar seus eleitores sobre o que fazem, como fazem, por que fazem e qual o valor do que fazem (Fenno, 1973).

Em relação à atividade parlamentar no caso brasileiro, mesmo com a força que a escola de estudos legislativos ganhou nos últimos anos, pouco foi feito sobre os discursos 
pronunciados pelos parlamentares em plenário ou mesmo fora do $\mathrm{CN}$. Sem ter os discursos como objeto principal de análise, muitos trabalhos se dedicaram a interpretar o posicionamento político dos representantes em temas específicos (meio ambiente, saúde, educação, política externa etc. $)^{5}$ ao analisar um pequeno volume de pronunciamentos ou debates ao longo do processo deliberativo de matérias (Antunes, 2016).

A única referência que se destaca nesse contexto de escassez é o trabalho de Miguel e Feitosa (2009), que, revertendo o quadro limitado do volume de discursos analisados, se dedicaram a uma amostra de quase 12 mil falas de deputados federais entre 1996 e 2006 para verificar as diferenças de conteúdo segundo o gênero do representante. Esses autores identificaram que é possível captar uma diferença temática com base no gênero do parlamentar, de modo que as mulheres em plenário se dedicam a temas distintos daqueles aos quais os homens se dedicam. Contudo, apesar do reconhecido esforço, trata-se de um único exemplo de análise sistemática dos discursos proferidos em plenário pelos parlamentares brasileiros. É com o objetivo de reforçar esse quadro que este artigo se apresenta.

\section{O foco no discurso do parlamentar brasileiro}

Os regimentos internos das duas Casas legislativas garantem a palavra como poder e direito do exercício parlamentar brasileiro. Os congressistas têm acesso a diversos meios de comunicação com recursos humanos e materiais financiados pela Câmara dos Deputados e o Senado Federal: TV, rádio, internet, jornal e outros canais institucionais. Assim, longe de ficarem restritos ao conteúdo das matérias em tramitação ou explicitamente apoiados na orientação de suas lideranças, regras menos restritivas regulam a participação e dedicam espaço de tempo exclusivo para o pronunciamento dos representantes brasileiros ${ }^{6}$.

Com regras que garantem a palavra como poder e direito do exercício parlamentar, os deputados federais e senadores, longe de ficarem submetidos ao conteúdo das matérias em tramitação, constantemente fazem uso estratégico de seu direito de fala. Pelo microfone acessam eleitores, colegas de plenário, os demais poderes da República e também a mídia nacional. A recente votação do processo de impeachment da presidenta da República Dilma Rousseff, ocorrida na CD em 17 de abril de 2016, é exemplo de uso estratégico da fala pelos deputados federais mesmo sob o regramento da votação nominal. Mais do que se posicionar contrária ou favoravelmente ao prosseguimento do processo, utilizaram a oportunidade para acessar seus eleitores e colegas de plenário. O deputado federal Glauber Braga (PSOL-RJ) registrou, por exemplo,

\footnotetext{
${ }^{5}$ Em relação ao discurso dos presidentes da República, ver, por exemplo, Vilela e Neiva (2011).

${ }^{6}$ Artigos de 69 a 81 e de 87 a 88 do Regimento Interno da Câmara dos Deputados, artigos de 156 a 161 do Regimento Interno do Senado Federal.
} 
sua indignação contra o processo e o presidente da $C D$, o deputado federal Eduardo Cunha (PMDB-RJ):

\begin{abstract}
Eduardo Cunha, você é um gângster. O que dá sustentação à sua cadeira cheira enxofre. Eu voto por aqueles que nunca escolheram o lado fácil da história. Eu voto por Marighella, eu voto por Plínio de Arruda Sampaio, eu voto por Evandro Lins e Silva, eu voto por Arraes, eu voto por Luís Carlos Prestes. Eu voto por Olga Benário. Eu voto por Brizola e Darcy Ribeiro. Eu voto por Zumbi dos Palmares. Eu voto não!?
\end{abstract}

Esse evento foi marcante na história política do país e as justificativas dadas a cada voto ganharam, inclusive, a repercussão na mídia internacional e foram objeto de análises de diversos comentaristas políticos pelo mundo ${ }^{8}$. Apesar de ser um evento isolado, a fala em destaque evidencia a adoção de um presentational style por parte do orador, buscando, entre outras coisas, cultivar apoio entre seus eleitores e correligionários (Fenno, 1973). Logo, em defesa da tese de que a atividade parlamentar não se restringe ao processo decisório e não está integralmente submetida aos seus constrangimentos institucionais, este artigo amplia o escopo tradicional de análise da atuação institucional dos deputados federais no Brasil e reconhece o discurso como um dos meios pelos quais a política se materializa.

Diferente das votações nominais e do processo de elaboração do conteúdo legislativo, a ciência política brasileira ainda desconhece quais variáveis governam a atividade discursiva do parlamentar no âmbito da Câmara dos Deputados, especialmente quando esta não se encontra submetida às regras do processo decisório. Por essa razão, fora das regras que regem as votações nominais e as tratativas para influenciar o conteúdo legislativo a ser apreciado, este artigo busca investigar como se distinguem os parlamentares em relação ao uso institucional dos momentos de fala disponíveis em plenário.

Através da análise exploratória de dados em conjunto com resultados advindos de modelos probabilísticos (Gelman, 2003, 2004, 2007, 2011), neste artigo são analisados os discursos proferidos pelos deputados federais brasileiros com o objetivo de identificar os padrões que regem sua frequência ao longo dos anos de 1999 a 2014, legislaturas de 51 a 54. Valendo-se da rica literatura que analisa a votação nominal na CD (Limongi e Figueiredo, 1998, 2005; Pereira e Mueller, 2000, 2002, 2003; Zucco Jr., 2009; Zucco Jr. e Lauderdale, 2011) e a produção do conteúdo legislativo aprovado (Freitas, 2010, 2013; Moreira, 2011; Ricci, 2003, 2006), o artigo é orientado pela seguinte questão: há indícios suficientes para afirmar que a comunicação parlamentar no âmbito da Câmara dos Deputados é governada pela relação governo-oposição, assim como constatado em sua atuação no processo decisório?

\footnotetext{
7 Discurso presente na página da Câmara dos Deputados (<www.camara.leg.br>), sem revisão do orador. 8 Para um exemplo, veja: <http://goo.gl/n3g8FA>. Acesso em: 14 ago. 2019.
} 
Uma vez que o objetivo deste artigo é ampliar o escopo de análise da atividade parlamentar na $C D$, convém resgatar as principais variáveis do debate desenvolvido ao longo de tantos anos em relação ao comportamento congressista. Por isso, são focos de análise aqui as seguintes variáveis: i) a classificação ideológica da legenda partidária pela qual o parlamentar foi eleito (esquerda ou centro/direita); ii) o posicionamento de sua legenda em relação ao governo (se o partido compôs ou não a coalizão governista ao longo da legislatura); iii) o percentual de votos recebidos pelo deputado federal na eleição que the conduziu à $C D$; iv) seu gênero; v) o número de legislaturas da qual fez parte em sua trajetória política após a Constituição Federal de 1988; vi) sua legenda partidária; vii) e a unidade federativa pela qual foi eleito.

Se os desdobramentos da tese do presidencialismo de coalizão proporcionaram um conhecimento apurado sobre o comportamento parlamentar em relação ao voto nominal e à produção legislativa no âmbito do processo decisório, a ciência política brasileira ainda pouco sabe sobre como os parlamentares se posicionam politicamente ao discursar. É com o objetivo de preencher essa lacuna e de contribuir para ampliar as dimensões de análise da atividade parlamentar no $\mathrm{CN}$ que este artigo se desenvolve. $\mathrm{Na}$ próxima seção serão apresentados os momentos institucionais de comunicação parlamentar na $C D$, justificada a escolha do Pequeno Expediente como objeto de análise e observada sua frequência de uso pelos deputados federais.

\section{A comunicação parlamentar na Câmara dos Deputados}

Realçada pelo processo de impeachment sofrido pela então presidenta da República Dilma Rousseff em 2016, a atividade parlamentar no âmbito da Câmara dos Deputados $(C D)$ vai além da votação e apresentação de projetos de lei. Entre outras atividades, o deputado federal possui tempo, espaço, recursos e infraestrutura dedicados à comunicação política que não se restringem aos projetos em pauta, garantindo à atividade parlamentar a oportunidade de não se submeter à agenda legislativa. Esse momento de fuga da agenda decisória já chegou inclusive a ser relatado em plenário. Segundo as palavras do deputado Wanderley Alves de Oliveira, "Deley" (PSC-RJ), em discurso proferido no dia 10 de junho de 2013 no Grande Expediente:

(...) neste dia de hoje, aproveitando esta oportunidade - porque todos sabemos que o Grande Expediente é feito através de sorteio e que, muitas vezes, é a chance para que possamos trazer parte daquilo que temos feito, parte de nossos pensamentos, até porque a dinâmica desta Casa muitas vezes nos dá poucas oportunidades - queremos estar falando com aquele companheiro, com aquela companheira, que muitas vezes, até por 
informações distorcidas, entende que trabalhamos aqui somente nas terças, quartas e, às vezes, quintas $(\ldots)^{9}$.

Em seu artigo 74, o Regimento Interno da Câmara dos Deputados (RICD) prevê sete possibilidades regimentais de fala para o parlamentar: (i) apresentar proposição; (ii) fazer comunicação ou versar sobre assuntos diversos, à hora do Expediente ou das Comunicações Parlamentares; (iii) tratar de proposição em discussão; (iv) levantar questão de ordem; (v) fazer reclamação; (vi) encaminhar a votação; e, a juízo do presidente da Casa, (vii) contestar acusação pessoal à própria conduta, feita durante a discussão, ou para contradizer o que lhe for indevidamente atribuído como opinião pessoal. Essa previsão de fala ocorre em oito momentos institucionais distintos: (i) Abertura; (ii) Breves Comunicações; (iii) Comissão Geral; (iv) Comunicações Parlamentares; (v) Grande Expediente; (vi) Homenagem; (vii) Ordem do Dia e (viii) Pequeno Expediente. Cada um desses momentos de fala possui regras próprias para a manifestação dos deputados federais (Tabela 1), mas é no Pequeno Expediente, no Grande Expediente, nas Comunicações Parlamentares e nas Breves Comunicações que os parlamentares têm a previsão regimental para tratar de assuntos diversos à pauta e podem discursar de forma livre na tribuna desde que dentro do tempo e das regras permitidos:

Tabela 1

Quadro comparativo da possibilidade de fala dedicada aos deputados federais

\begin{tabular}{|l|c|c|}
\hline $\begin{array}{c}\text { Situação } \\
\mathbf{n}^{\circ}\end{array}$ & Possibilidade de fala & $\begin{array}{c}\text { Dispositivos } \\
\text { regimentais }\end{array}$ \\
\hline 1 & Apresentar proposição & Art. 132 \\
\hline 2 & $\begin{array}{c}\text { Fazer comunicação ou versar sobre assuntos diversos, à hora } \\
\text { das Breves Comunicações, do Pequeno Expediente, do Grande } \\
\text { Expediente ou das Comunicações Parlamentares }\end{array}$ & $\begin{array}{c}\text { Art. 66, I, II e IV; } \\
\text { arts. 81, 87 e 90 }\end{array}$ \\
\hline 3 & Discutir proposição em pauta & $\begin{array}{c}\text { Art. 157, § 30; arts. } \\
\text { de 171 a 176 }\end{array}$ \\
\hline 4 & Formular questão de ordem ou contra-argumentar & Art. 95 \\
\hline 5 & Apresentar reclamação & Art. 96 \\
\hline 6 & Encaminhar votação & Art. 192 \\
\hline 7 & $\begin{array}{c}\text { Contestar acusação pessoal à própria conduta, feita durante } \\
\text { discussão, ou contradizer o que lhe for atribuído indevidamente } \\
\text { como opinião pessoal }\end{array}$ & - \\
\hline
\end{tabular}

Fonte: Curso de Regimento Interno, p. 246. Com ajustes.

É justamente pelo fato de a fala parlamentar ter a possibilidade de se concretizar em ambiente de relativa independência em relação ao processo decisório que este artigo busca investigar como se distinguem os parlamentares em relação à sua frequência de discursos proferidos em plenário e avançar na análise de outras dimensões da atividade parlamentar. Para esses propósitos, portanto, as Breves Comunicações, as Comunicações

\footnotetext{
${ }^{9}$ Discurso presente na página da Câmara dos Deputados (<www.camara.leg.br>), sem revisão do orador.
} 
Parlamentares, o Pequeno e o Grande Expedientes se caracterizam como momentos institucionais ideais para análise. A seguir, apresento as principais características desses momentos institucionais, justifico a escolha do Pequeno Expediente como foco deste artigo e analiso a fundo a frequência de uso desse momento institucional pelos deputados federais ao longo de 1999 a 2014.

\section{Momentos institucionais de fala livre}

As sessões ordinárias da CD, com duração de cinco horas (art. 66, RICD), possuem quatro fases, nessa ordem: Pequeno Expediente, Grande Expediente, Ordem do Dia e Comunicações Parlamentares. Nos Pequeno e Grande Expedientes e nas Comunicações Parlamentares, os deputados têm liberdade para tratar dos temas e questões que consideram pertinentes sem os constrangimentos das regras do processo decisório. Ademais, apesar de não se tratar de uma fase regimental das sessões ordinárias, conforme é exposto adiante, nas Breves Comunicações os parlamentares também se encontram livres dos constrangimentos do processo decisório ${ }^{10}$. Cada um desses momentos previstos no RICD tem sua peculiaridade, e suas regras podem interferir em maior ou menor grau na possibilidade de seu uso por parte dos parlamentares (Tabela 2):

Tabela 2

Quadro comparativo - Momentos institucionais de fala selecionados

\begin{tabular}{|c|c|c|c|}
\hline $\begin{array}{l}\text { Momento } \\
\text { institucional }\end{array}$ & Regras gerais & $\begin{array}{l}\text { Tempo } \\
\text { de fala }\end{array}$ & $\begin{array}{l}\text { Dispositivos } \\
\text { regimentais } \\
\text { (RICD) }\end{array}$ \\
\hline $\begin{array}{l}\text { Pequeno } \\
\text { Expediente }\end{array}$ & $\begin{array}{c}\text { Inscrição dos oradores feita na Mesa, em caráter pessoal e } \\
\text { intransferível, diariamente, assegurada a preferência aos que } \\
\text { não hajam falado nas cinco sessões anteriores. As inscrições que } \\
\text { não puderem ser atendidas serão transferidas para a sessão } \\
\text { ordinária seguinte. Não é permitido o aparte. }\end{array}$ & $5^{\prime}$ & $\begin{array}{c}\text { Arts. } 66,75 \text {, de } 79 \text { a } \\
81,176\end{array}$ \\
\hline $\begin{array}{l}\text { Grande } \\
\text { Expediente }\end{array}$ & $\begin{array}{l}\text { Lista de oradores definida mediante sorteio, limitando cada } \\
\text { deputado a falar no máximo três vezes por semestre, sendo uma } \\
\text { por sorteio e duas por cessão de vaga de outro parlamentar. } \\
\text { Pode ser reservado para honraria. São permitidos apartes. }\end{array}$ & $25^{\prime}$ & $\begin{array}{c}\text { Arts. } 66,68,73,87, \\
88,221,222\end{array}$ \\
\hline $\begin{array}{l}\text { Comunicações } \\
\text { Parlamentares }\end{array}$ & $\begin{array}{c}\text { Ocorre somente se a Ordem do Dia se encerrar antes do tempo } \\
\text { previsto. A inscrição é feita por meio das lideranças partidárias. } \\
\text { É permitido o aparte. }\end{array}$ & $10^{\prime}$ & Arts. $66,73,90$ \\
\hline $\begin{array}{l}\text { Breves } \\
\text { Comunicações }\end{array}$ & $\begin{array}{l}\text { Tempo dedicado à fala dos parlamentares caso haja } \\
\text { disponibilidade após a leitura da matéria do Expediente. A } \\
\text { inscrição dos oradores é feita na Mesa, em caráter pessoal e } \\
\text { intransferível, assegurada a preferência aos que não hajam } \\
\text { falado nas cinco sessões anteriores. Não é permitido o aparte. }\end{array}$ & $5^{\prime}$ & Arts. 67,81 \\
\hline
\end{tabular}

Fonte: Curso de Regimento Interno, p. 246. Com ajustes.

10 Após consulta feita ao Departamento de Taquigrafia da Câmara dos Deputados sobre a existência ou não da fase "Breves Comunicações" nas sessões legislativas, houve informação de que há previsão dessa fase nas sessões extraordinárias da Câmara dos Deputados e nas sessões do Congresso Nacional (artigos 67 e 81 do RICD e artigo 31 do Regimento Comum do Congresso Nacional - RCCN). 
O Pequeno Expediente (primeira fase), com duração regimental de 60 minutos ${ }^{11}$, é dedicado à leitura da matéria do Expediente ${ }^{12}$ e aos oradores inscritos. Segundo o RICD, abertos os trabalhos de uma sessão legislativa, no Pequeno Expediente os deputados federais podem falar por até cinco minutos num intervalo de 60 minutos em cada sessão legislativa. A inscrição dos oradores é feita na Mesa, em caráter pessoal e intransferível, em livro próprio, das 8 às 13 horas e 30 minutos, diariamente, assegurada a preferência aos que não hajam falado nas cinco sessões anteriores. As inscrições que não puderem ser atendidas em virtude da não realização da sessão serão transferidas para a sessão ordinária seguinte.

No Grande Expediente, segunda fase, cada parlamentar pode discursar por até 25 minutos num intervalo de 50 minutos. A lista de oradores para o Grande Expediente é definida mediante sorteio, limitando cada deputado a falar no máximo três vezes por semestre, sendo uma por sorteio e duas por cessão de vaga de outro parlamentar. 0 deputado federal que não falar por falta de vaga terá assegurada a preferência de inscrição no semestre seguinte. Ademais, como indica o artigo 88 do RICD: "A Câmara poderá destinar o Grande Expediente para comemorações de alta significação nacional, ou interromper os trabalhos para a recepção, em Plenário, de altas personalidades, desde que assim resolva o presidente, ou delibere o Plenário".

As Comunicações Parlamentares configuram a quarta fase das sessões ordinárias da CD. No entanto, elas só ocorrerão se a Ordem do Dia se encerrar antes do horário previsto (19h). A inscrição é feita por meio das lideranças partidárias e cada fala deve ter até dez minutos, sendo os oradores alternados de acordo com partidos e blocos parlamentares inscritos.

O momento institucional chamado de Breves Comunicações, conhecido também como "pinga-fogo", refere-se ao tempo que sobra logo após a primeira fase (Pequeno Expediente). Não se trata de uma fase da sessão ordinária da $C D$, mas, havendo disponibilidade de tempo, os deputados federais inscritos diretamente na Mesa podem falar por cinco minutos, não sendo permitidos apartes.

Como é possível concluir com base nas regras que regem todos os momentos institucionais nos quais os parlamentares podem fazer uso livre da palavra, o Pequeno Expediente é o momento que permite maior acesso e liberdade por parte do deputado para expor suas ideias e proferir seu discurso. Em relação às Comunicações Parlamentares e às Breves Comunicações, há a vantagem de não dependerem da sobra de tempo para sua realização. Além do que, nas Comunicações Parlamentares a inscrição do orador é feita pelo líder do partido ou da bancada.

\footnotetext{
${ }^{11}$ É importante destacar que há previsão de espera de 30 minutos para preenchimento do quórum mínimo de abertura da sessão. Esse tempo deverá ser deduzido do período destinado ao Expediente (art. 79, § 30 RICD).

12 A matéria do Expediente consiste nas comunicações enviadas à Mesa pelos deputados federais, na correspondência em geral, nas petições e em outros documentos recebidos pelo presidente ou pela Mesa, de interesse do Plenário.
} 
No Grande Expediente, o parlamentar pode discursar no máximo por três vezes no semestre e totalizar 75 minutos de discurso, enquanto no Pequeno Expediente um parlamentar pode discursar uma vez por semana e chegar à marca de 120 minutos de discurso no semestre. Ademais, as regras de inscrição do Grande Expediente são restritivas, pois, de forma geral, permitem que, no máximo, 240 deputados diferentes possam discursar no semestre ${ }^{13}$. Já as regras do Pequeno Expediente permitem que até 1.440 deputados diferentes possam discursar ao longo período, número que representa quase três vezes o de deputados federais ${ }^{14}$.

O Pequeno Expediente, além de se caracterizar como momento de livre comunicação parlamentar, produz um número maior de pronunciamentos e abrange maior número de deputados federais, pois são dedicados cinco minutos para cada orador num total de 60 minutos em cada sessão legislativa ${ }^{15}$. Sua presença no RICD atual advém de sua primeira publicação após a Constituição Federal de 1988. No entanto, já no RICD de 1947, aprovado por meio da resolução 10/47 após apreciação do PRC 09/47, o Pequeno Expediente era tido como uma parte do Expediente, pois estava prevista a inscrição de oradores para fala após a leitura do Expediente em cada sessão pública. Apesar de não ter sido estipulado no regimento interno da época, até a resolução 18/63 (aprovada através do PRC 04/63), que institucionalizou o Pequeno Expediente regulamentando suas regras no $\mathrm{RICD}^{16}$, esse momento de fala já era nomeado pelos parlamentares como Pequeno Expediente ${ }^{17}$.

Ao longo do período de 1946 até a inclusão efetiva do Pequeno Expediente no RICD em 1963, não faltaram momentos de dúvida e crítica sobre os critérios utilizados pela Mesa para inscrição e fala dos deputados federais. Em dezembro de 1956, por exemplo, o deputado federal Jefferson de Aguiar (PSD-ES) fez críticas à Mesa a respeito da permissão de fala de parlamentares não inscritos no Expediente ( $D C D$ 12/12/56, p.

\footnotetext{
13 Esse número pode ser maior, pois o artigo 85 do RICD permite ao presidente da Casa não designar Ordem do Dia para as sessões ordinárias e convertê-las em sessões de debates (art. $66, \S 3^{\circ}$ ). Além disso, o presidente não pode designar Ordem do Dia para a primeira sessão plenária das sessões legislativas ordinárias e das sessões legislativas extraordinárias (art. 85, parágrafo único). Esse dispositivo, permite, portanto, maior tempo de debate e, consequentemente, um maior número de oradores. A título de exemplo, a terceira sessão legislativa extraordinária da $52^{a}$ Legislatura foi inaugurada em sessão conjunta solene no dia 19 de janeiro de 2004. Nesse dia, a sessão teve o Pequeno Expediente e o Grande Expediente, este composto por 29 oradores (Curso de Regimento Interno, p. 253).

14 Para calcular esses números, consideramos semanas com cinco dias de sessão legislativa e meses com quatro semanas. Logo, os números reais podem ser menores se considerarmos feriados ou demais imprevistos como, por exemplo, a recepção de altas personalidades, conforme prevê o RICD.

15 Neste artigo, chamamos de pronunciamento toda fala registrada em qualquer um dos seguintes momentos institucionais previstos no RICD: Abertura, Breves Comunicações, Comissão Geral, Comunicações Parlamentares, Grande Expediente, Homenagem, Ordem do Dia e Pequeno Expediente.

${ }^{16}$ Ao analisar esse histórico, há indícios de que a regulamentação do Pequeno Expediente esteja vinculada à aprovação da Lei 4.095/62, que aumentou o número de deputados federais de 326 para 404 por meio do Projeto de Lei $2.787 / 61$.

17 A título de exemplo, o discurso do deputado Celso Peçanha (PTB-RJ), realizado em 21 de dezembro de 1954 e publicado no Diário da Câmara dos Deputados em 28 de dezembro de 1954 (p. 8.873), destaca a existência, ainda informal, do Pequeno Expediente.
} 
12.456), questão que foi tratada na sessão seguinte pelo presidente ( $D C D$ 13/12/56, p. 12.549). Nas palavras do deputado federal Jefferson Aguiar (PSD-ES):

Sr. Presidente, estimei tivesse V. Excia. reassumido a direção dos trabalhos, para que (muito bem), porque, enquanto Vossa Excia. Vice-Presidente da Casa esteve afastado da Mesa, vários oradores não inscritos falaram. Alguns deles, com inscrição posterior à minha, fizeram uso da palavra dentro do regime simpatético vigente e que lamentamos (...).

Em 1963, através da resolução 18/63, o Pequeno Expediente ganha basicamente os moldes que hoje possui, sendo ele incorporado pelo RICD de 1989 (resolução 17/89). Presente de modo informal desde o regime democrático de 1946, esse momento sempre se caracterizou pela livre comunicação parlamentar e pela garantia de acesso a todos os deputados federais que desejassem alguns minutos de fala.

Se, com base nas regras que regem os momentos de fala livre dos parlamentares, se identifica que o Pequeno Expediente possui vantagens comparativas, resta saber se essa vantagem ocorre na prática. A seguir, são apresentadas informações referentes ao uso do Pequeno Expediente ao longo das legislaturas analisadas após a Constituição Federal de 1988.

\section{O uso da fala na Câmara dos Deputados}

De acordo com os dados disponibilizados pela CD, dos 281.450 pronunciamentos realizados ao longo das legislaturas analisadas, 95,9\% foram realizados por deputados federais $^{18}$ (Figura 2) ${ }^{19}$. A realização de 270.014 pronunciamentos pelos deputados federais ao longo de 16 anos, uma média de quase 17 mil ao ano, evidencia a relevância da comunicação política no âmbito da CD:

\footnotetext{
18 É importante ressaltar que outras autoridades (ministros, secretários, prefeitos ou personalidades convidadas) têm pronunciamentos registrados nos dados da CD. Por isso o pronunciamento dos deputados federais não atinge $100 \%$.

19 Uma das razões para o baixo número de pronunciamentos apresentado em relação à $51^{a}$ legislatura é o fato de a disponibilidade dos registros nos dados abertos da CD para essa legislatura terem começado somente em 5 de outubro de 2000 e não em 2 de fevereiro de 1999, quando se iniciou a respectiva legislatura. Para os fins deste artigo, o montante registrado se faz relevante.
} 
Figura 2

Quantidade de pronunciamentos realizados por deputados federais por legislatura

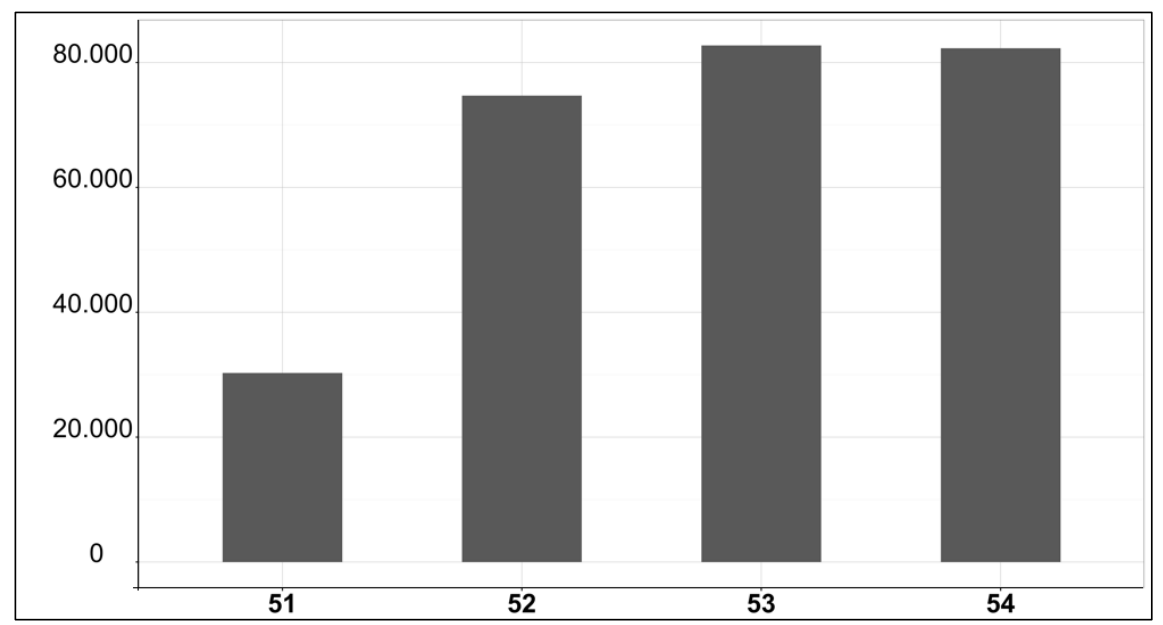

Fonte: Elaboração própria com base em dados da Câmara dos Deputados.

A grande maioria dos mais de 270 mil pronunciamentos foi realizada durante o Pequeno Expediente (Figura 3), sendo ele o principal meio de comunicação da CD ao longo de todos os anos analisados, com exceção de 2013, terceiro ano da 54a legislatura, quando apresentou uma pequena baixa em relação às Breves Comunicações ${ }^{20}$. Nos demais anos, a preponderância do Pequeno Expediente é nítida, conforme apresenta a Figura 4: 
Figura 3

Proporção de uso dos momentos institucionais de pronunciamento pelos deputados federais

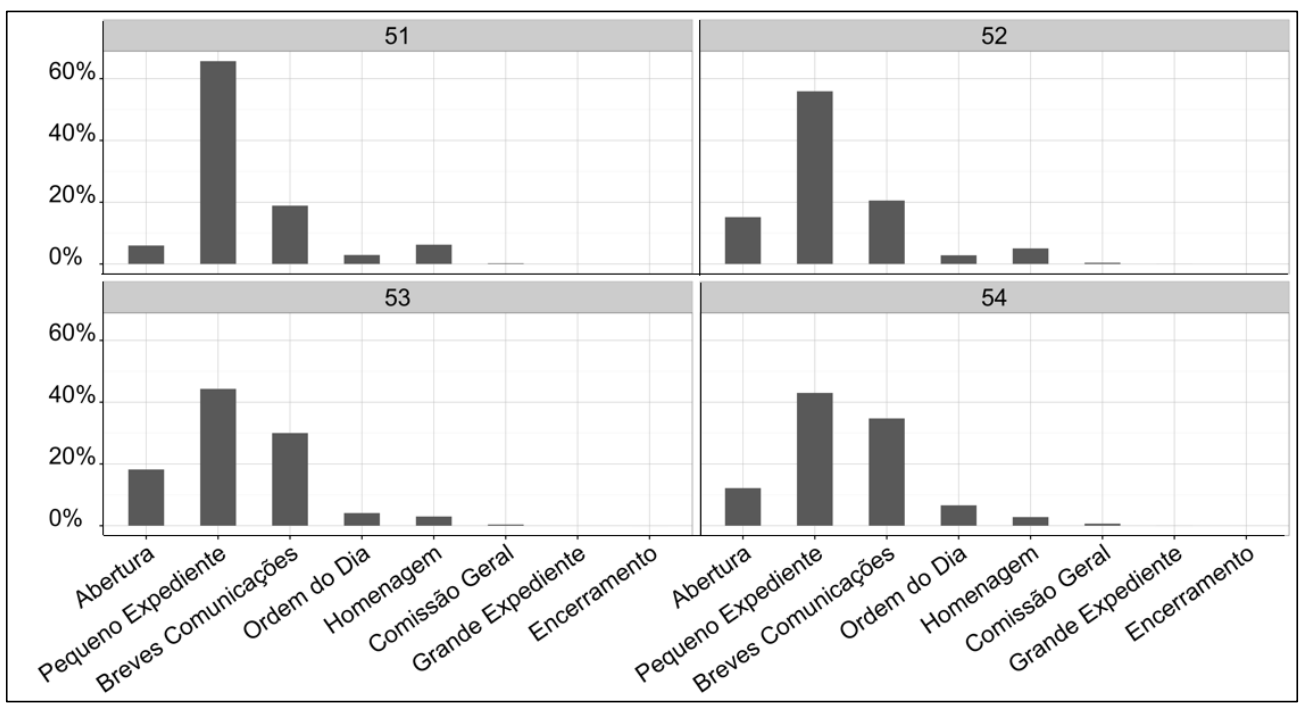

Fonte: Elaboração própria com base em dados da Câmara dos Deputados.

Figura 4

Pronunciamentos realizados pelos deputados federais por ano segundo o momento institucional

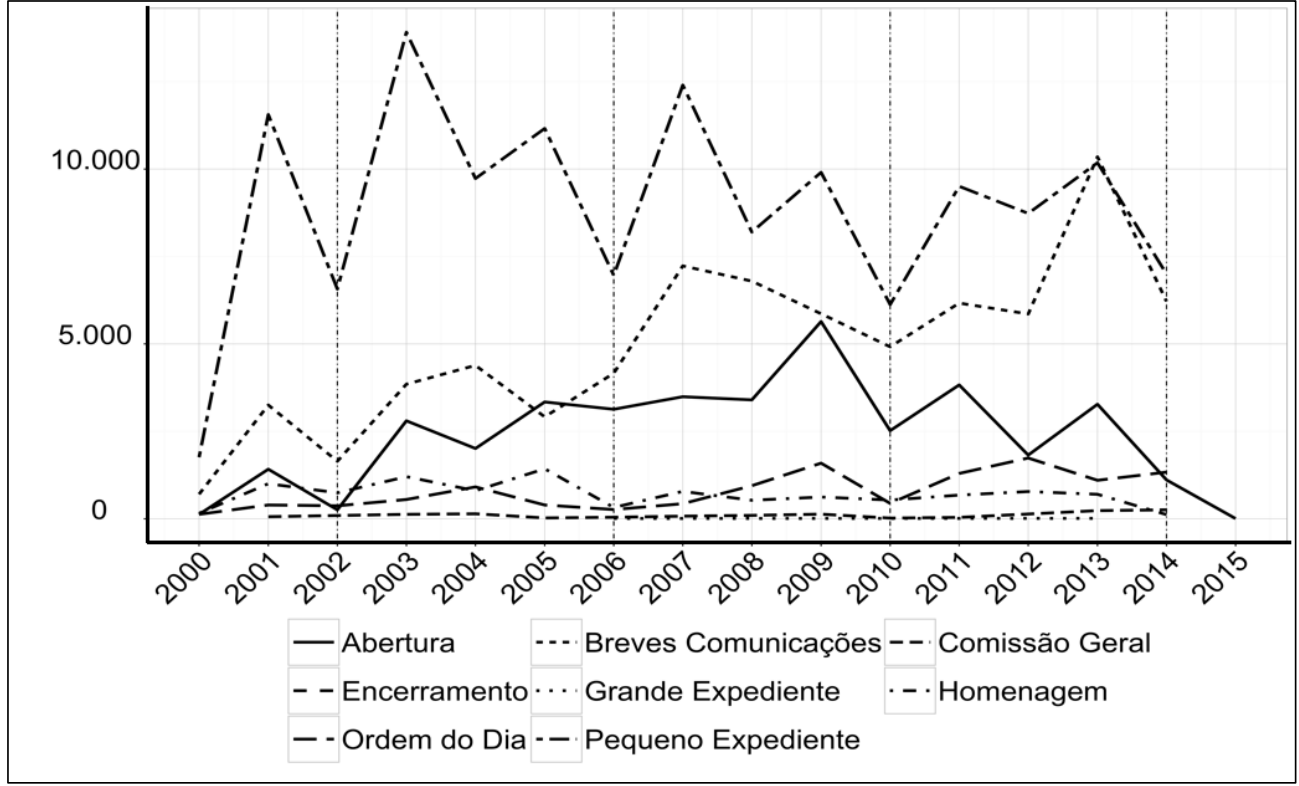

Fonte: Elaboração própria com base em dados da Câmara dos Deputados. 
Se a quantidade de pronunciamentos realizados ao longo de 16 anos evidencia a importância do uso da fala no desenvolvimento da atividade parlamentar no âmbito da CD, as Figuras 3 e 4 deixam clara a relevância do Pequeno Expediente em relação a todos os momentos institucionais de pronunciamento parlamentar. Ademais, é importante relembrar que as regras que regem o Pequeno Expediente são, em comparação com as que regem os demais momentos de fala, as que permitem maior acesso dos deputados federais à tribuna e garantem liberdade temática ao discurso proferido. É em virtude de tamanha relevância que esse momento institucional foi escolhido como objeto deste artigo e, portanto, justifica a necessidade de uma análise mais apurada. Fazendo alusão a um karaokê e à liberdade de inscrição dos cantores (ou pseudocantores), quais variáveis governam o livre acesso ao microfone no plenário da $\mathrm{CD}$ ? A seguir, é apresentada uma análise minuciosa a respeito do uso desse momento institucional.

\section{O Pequeno Expediente e o padrão de atuação parlamentar}

Um total de 2.579 deputados federais diferentes compuseram as legislaturas analisadas $^{21}$. Destes, $2.262(87,7 \%)$ realizaram ao menos um discurso no Pequeno Expediente $^{22}$, sendo que utilizaram essa oportunidade de forma diversa entre si conforme apresenta a Figura 5:

\section{Figura 5}

\section{Dispersão da quantidade de discursos dos} deputados federais no Pequeno Expediente

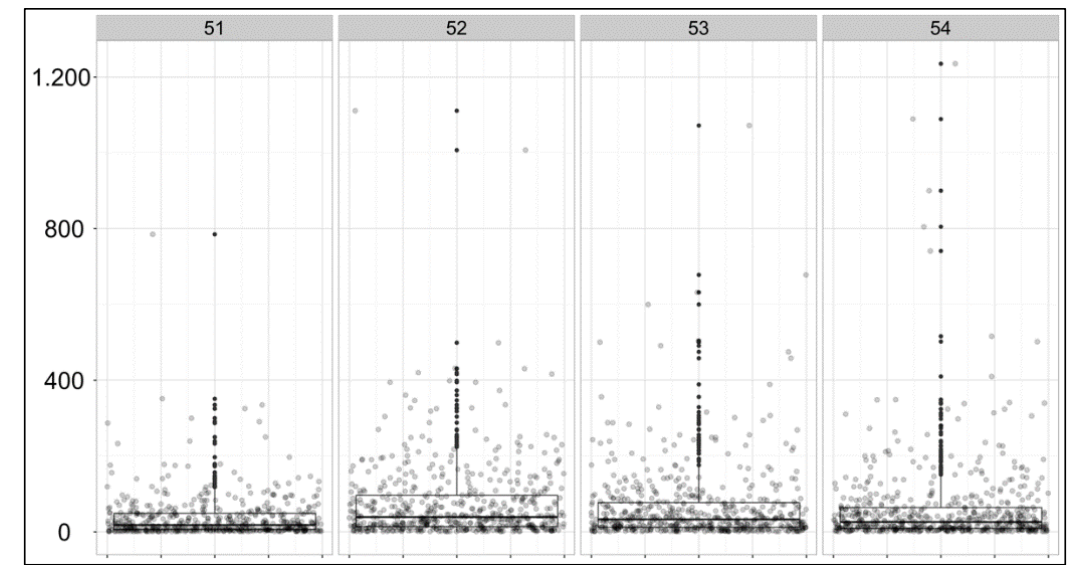

Fonte: Elaboração própria com base em dados da Câmara dos Deputados.

Descrição: Além do boxplot, cada ponto representa um deputado federal que realizou ao menos um discurso no Pequeno Expediente na respectiva legislatura.

21 Cada pessoa foi contabilizada mais de uma vez conforme o número de legislaturas da qual tenha participado. Essa escolha foi feita pois, em cada legislatura, um cidadão eleito deputado federal torna-se um orador em potencial.

${ }^{22}$ Como uma mesma pessoa pode ter sido eleita mais de uma vez ao longo das legislaturas de 51 a 54 , os 2.262 oradores do Pequeno Expediente representam 1.333 pessoas distintas. 
Há, em média, 58,7 discursos proferidos no Pequeno Expediente por deputado federal que proferiu algum discurso ${ }^{23}$. No entanto, como verificamos na Figura 5, enquanto alguns parlamentares discursaram apenas uma vez (97 ao todo), outros discursaram centenas de vezes e alguns poucos ultrapassaram a marca de mil discursos numa única legislatura. A Tabela 3 apresenta os dados descritivos da quantidade de discursos proferidos no Pequeno Expediente por deputado federal em cada legislatura:

Tabela 3

Dados descritivos da quantidade de discursos no Pequeno Expediente por deputado federal em cada legislatura

\begin{tabular}{|l|c|c|c|c|}
\hline & $\mathbf{5 1}$ & $\mathbf{5 2}$ & $\mathbf{5 3}$ & $\mathbf{5 4}$ \\
\hline Mínimo & 0 & 0 & 0 & 0 \\
\hline Quartil 1 & 2 & 9 & 7 & 5 \\
\hline Mediana & 10 & 34 & 27 & 20 \\
\hline Média & 30,9 & 66,7 & 57,6 & 52,8 \\
\hline Quartil 3 & 41 & 87,5 & 70,5 & 55 \\
\hline Máximo & 785 & 1.111 & 1.072 & 1.235 \\
\hline No zeros & 118 & 54 & 63 & 80 \\
\hline No deputados & 526 & 572 & 573 & 591 \\
\hline No discursos & 19.883 & 41.756 & 36.613 & 35.398 \\
\hline
\end{tabular}

Fonte: Elaboração própria com base em dados da Câmara dos Deputados.

Constata-se, portanto, que o uso dos recursos de comunicação disponíveis no Pequeno Expediente varia de acordo com cada parlamentar, indicando que a propensão ao discurso pode advir de características pessoais de cada um. Contudo, para além de anseios e motivações individuais, a literatura que analisa a atividade parlamentar na CD indica que ao menos duas coleções de variáveis orientariam o comportamento individual.

De um lado, variáveis advindas da arena eleitoral, que destacam características do distrito pelo qual foi eleito o deputado federal, pois seria conveniente para o parlamentar agir em função de seu eleitorado, uma vez que teria interesse em receber seu apoio político em futuras eleições (Ames, 1995b, 2002; Mainwaring, 1991, 1999; Pereira e Mueller, 2002, 2003). Com base na tese do voto pessoal (Cain, Ferejohn e Fiorina, 1990), o sistema eleitoral proporcional de lista aberta brasileiro determinaria o comportamento legislativo do representante.

De outro, variáveis presentes na arena legislativa, que destacam características da legenda partidária à qual o parlamentar é filiado (e.g., ideologia, governo ou oposição), pois a composição da maioria legislativa através da distribuição de pastas ministeriais, somada às regras que regem o processo decisório e organizam os trabalhos na $C D$, orientaria o comportamento partidário de modo que assim o parlamentar

23 Como vimos, considerando os possíveis oradores em cada legislatura, 317 deles (12,3\% de 2.578) não realizaram qualquer discurso no Pequeno Expediente. 
obtivesse créditos políticos e recursos para beneficiar seu eleitorado (Figueiredo e Limongi, 2002, 1999; Limongi e Figueiredo, 1998; Zucco Jr., 2009).

Considerando a legenda partidária como uma referência teórica para explicação do uso dessa oportunidade de comunicação, quanto maior a quantidade de parlamentares, maior a chance de uma legenda se fazer presente na tribuna. 0 coeficiente de correlação de Pearson entre o número de discursos no Pequeno Expediente e o número de deputados por partido apresenta os seguintes resultados para as legislaturas 51, 52, 53 e 54: 0,86;0,93;0,95; 0,9324. No entanto, sabendo que o uso do Pequeno Expediente varia de acordo com o número de parlamentares de cada partido e, como visto (Figura 5), entre os próprios deputados federais, a legenda partidária pode otimizar de forma distinta sua presença na tribuna. Assim, a razão entre a quantidade de discursos proferidos e a quantidade de potenciais oradores (Figura 6) apresenta o uso dos recursos disponíveis (parlamentares) para marcar presença (discursar) no Pequeno Expediente por parte de cada partido.

\section{Figura 6 \\ Quantidade de discursos por legenda partidária no Pequeno Expediente em relação a seus possíveis oradores}

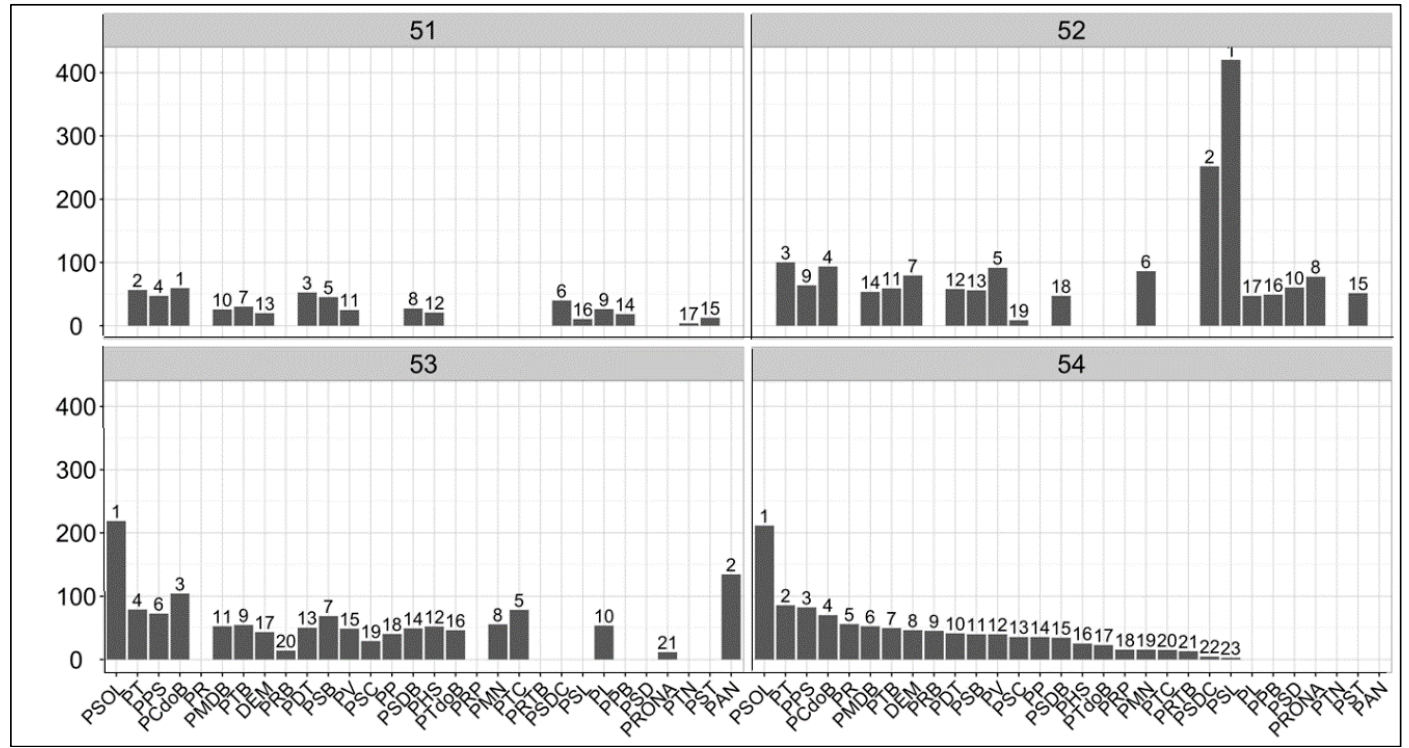

Fonte: Elaboração própria com base em dados da Câmara dos Deputados.

Descrição: Os valores acima das barras representam a posição de cada legenda partidária no ranking de discursos per capita.

24 É importante ressaltar novamente que neste artigo cada parlamentar foi associado à legenda partidária pela qual se elegeu numa determinada legislatura, a despeito de uma eventual troca de legenda ao longo do mandato. 
Com exceção da legislatura 52 (2003-2007), observa-se na Figura 6 que alguns dos partidos de esquerda (PSOL, PT, PPS e PCdoB) aproveitam melhor a infraestrutura de comunicação disponível no Pequeno Expediente. Tal conclusão é observada quando se compara a quantidade de discursos proferidos pelos parlamentares do partido com a quantidade de potenciais oradores que a legenda teve ao longo de cada legislatura25.

Se em relação à legenda partidária é possível constatar uma certa preponderância de uso da tribuna por parte de deputados federais eleitos por partidos de esquerda, cabe perguntar: como as principais variáveis presentes nas análises sobre o comportamento parlamentar na CD influenciam a disposição do deputado federal em discursar no Pequeno Expediente? Em linha com a literatura sobre a atividade parlamentar na $C D$, cabe aqui enunciar novamente a pergunta deste artigo: há indícios suficientes para afirmar que a comunicação parlamentar no âmbito da Câmara dos Deputados é governada pela relação governo-oposição, assim como constatado em sua atuação no processo decisório?

\section{A relação governo-oposição na comunicação parlamentar}

A princípio simples, a relação governo-oposição impõe sérios desafios à modelagem estatística. Adotando como variável a ser predita, $y_{i}$, a frequência de discursos proferidos no Pequeno Expediente de cada deputado federal, $i, i \in\{1, \ldots, n\}$, que tomou posse ao longo das legislaturas analisadas, foi estimado um modelo hierárquico bayesiano em que o primeiro nível se refere aos parlamentares, sendo estes pertencentes a suas respectivas legendas partidárias, $j, j \in\{1, \ldots, J\}$, e unidades federativas, $k, k \in\{1, \ldots, K\}$. Variando o intercepto em função da legenda partidária e da unidade federativa (UF) de cada potencial orador, no modelo estão incluídos preditores individuais para os deputados federais, preditores para as legendas partidárias e preditores que destacam as características de cada UF, conforme exposto na Tabela 4. Na equação, adotou-se $X$ para representar a matriz de variáveis preditoras, $\beta$ representa o vetor de coeficientes e deput,part, uf são os respectivos indexadores para os deputados federais, as legendas partidárias e as UFs.

A escolha para a modelagem multinível está baseada na estrutura hierárquica do processo de seleção dos possíveis oradores do Pequeno Expediente. Antes de se tornarem deputados federais, todos os possíveis oradores foram candidatos filiados a legendas partidárias em suas respectivas UFs e estiveram submetidos ao escrutínio público de cada localidade. Desse modo, é importante conceber que, além de variáveis

\footnotetext{
25 Diversos trabalhos se dedicaram a classificar parlamentares e legendas partidárias sobre o espectro ideológico (Leoni, 2002; Power e Zucco, 2009; Tarouco e Madeira, 2013; Zucco, 2009; Zucco Jr. e Lauderdale, 2011). Neste artigo, com base nas pesquisas de Zucco (2009) e Power e Zucco (2009), optouse por identificar apenas os partidos de esquerda: PCdoB, PDT, PPS, PSB, PSOL e PT. Assim, neste artigo a variável ideologia assume os valores "Esquerda" e "Centro/Direita".
} 
pessoais, variáveis vinculadas à legenda partidária e à realidade de cada UF podem ter interferência sobre a futura disposição do parlamentar eleito para fala.

Tabela 4

Variáveis preditoras

\begin{tabular}{|c|c|}
\hline \multicolumn{2}{|r|}{ Deputados federais } \\
\hline Variável & Descrição \\
\hline Mulher & Variável indicando se o parlamentar é do sexo feminino \\
\hline$\%$ Votos & Percentual de votos recebidos na UF \\
\hline No Legislatura & $\begin{array}{c}\text { Quantidade de legislaturas da qual o parlamentar fez parte após } 1988 \text { até a } \\
\text { respectiva legislatura }\end{array}$ \\
\hline \multicolumn{2}{|r|}{ Legendas partidárias } \\
\hline Variável & Descrição \\
\hline Esquerda & $\begin{array}{c}\text { Variável indicando se a legenda partidária pela qual o parlamentar foi eleito é } \\
\text { classificada ideologicamente de esquerda ou centro/direita }\end{array}$ \\
\hline Coalizão & $\begin{array}{c}\text { Variável indicando se a legenda partidária pela qual o parlamentar foi eleito compôs } \\
\text { a coalizão governista ao longo da legislatura }\end{array}$ \\
\hline \multicolumn{2}{|r|}{$\begin{array}{c}\text { Unidades federativas } \\
\end{array}$} \\
\hline Variável & Descrição \\
\hline PIB per capita & PIB per capita da UF no ano de 2010 \\
\hline
\end{tabular}

Fonte: Elaboração própria a partir da revisão da literatura.

Ademais, convém ressaltar que não é realizada qualquer inferência causal a respeito das variáveis preditoras sobre a variável predita. Resguardada essa limitação analítica, a estrutura do modelo adotado é utilizada com o objetivo de verificar correlações robustas entre a variável predita e as variáveis preditoras (Gelman e Hill, 2006). O arcabouço estatístico utilizado permite, portanto, obter evidências a respeito da predição que as variáveis listadas na Tabela 4 possuem sobre a quantidade de discursos proferida por um parlamentar numa respectiva legislatura ${ }^{26}$.

$$
\begin{gathered}
y_{i} \sim \operatorname{Bin}-\operatorname{neg}\left(\mu_{i}, \phi\right), \text { onde } \\
E\left(y_{i}\right)=\mu_{i} \text { e } \operatorname{Var}\left(y_{i}\right)=\frac{\mu_{i}+\mu_{i}^{2}}{\phi}, \text { cuja função de ligação é dada por: } \\
\log \left(\mu_{i}\right)=X_{i} \beta^{\text {deput }}+\alpha_{j[i]}^{\text {part }}+\alpha_{k[i]}^{u f} \text {, para } i=1, \ldots, n \\
\alpha_{j}^{\text {part }} \sim \mathrm{N}\left(X_{j} \beta^{\text {part }}, \sigma_{\text {part }}^{2}\right) \text {, para } j=1, \ldots, J \\
\alpha_{k}^{u f} \sim \mathrm{N}\left(X_{k} \beta^{u f}, \sigma_{u f}^{2}\right) \text {, para } k=1, \ldots, K .
\end{gathered}
$$

26 Agradeço a dedicação e o profissionalismo da equipe de pesquisadoras do Núcleo de Estudos Comparados e Internacionais (Neci), que, de forma muito gentil, contribuiu para este artigo disponibilizando dados de todos os deputados federais eleitos. Em especial, agradeço à Profa. Dra. Andréa Freitas e às pesquisadoras Alexia Aslan, Andréa Junqueira, Graziele Silotto e Joyce Luz. 
A distribuição binomial negativa pode ser utilizada como substituta da distribuição de Poisson em modelos de contagem, especialmente quando os dados apresentam sobredispersão (overdispersion). Ela é governada por dois parâmetros, $\mu$ e $\phi$, conforme apresentado. No conjunto de equações, $\mu$ é o valor esperado de $y$ obtido por meio da função de ligação $\log$. Por sua vez, $\phi$ é o parâmetro de sobredispersão, cuja magnitude ajuda a identificar em que medida a distribuição binomial negativa se assemelha à distribuição de Poisson ${ }^{27}$.

Para a estimação bayesiana foram adotadas duas prioris não informativas, uma para os parâmetros $\beta$ e outra para o intercepto $\alpha$, confome indica o conjunto de equações ${ }^{28}$ :

$$
\begin{gathered}
\alpha \sim \mathrm{N}(0,5) \\
\beta \sim \mathrm{N}(0,2,5)
\end{gathered}
$$

A Figura 7 apresenta os principais resultados obtidos na estimação do modelo. Cada intervalo de credibilidade estimado está representado por uma linha sólida, que permite concluir com 95\% de probabilidade o intervalo que o coeficiente pode assumir. Assim, caso a linha sólida não cruze a linha tracejada do zero, pode-se interpretar com $95 \%$ de credibilidade o efeito da variável preditora sobre a variável predita.

Figura 7

Intervalos de credibilidade estimados para cada legislatura

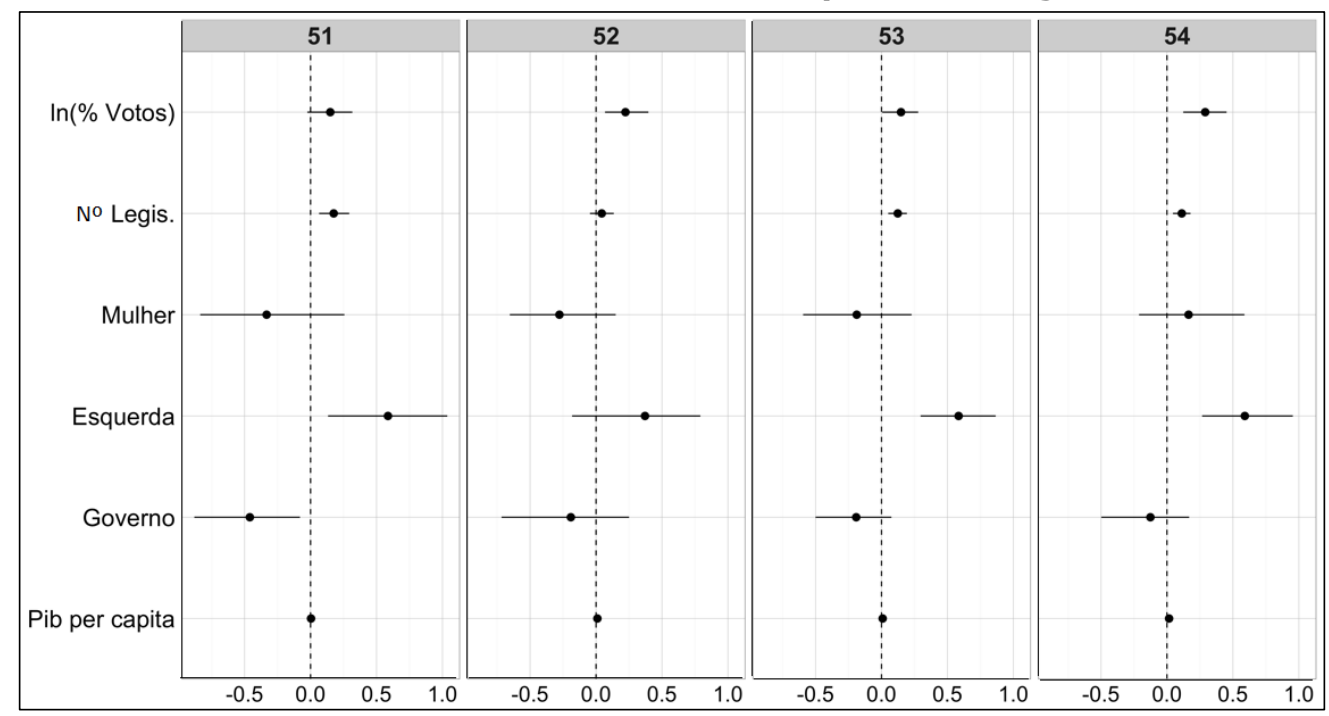

Fonte: Elaboração própria com base nos resultados do modelo apresentado.

Nota: Dada a quantidade de unidades federativas, optou-se por omitir seus resultados nessa visualização. Para detalhes, consulte o Apêndice Metodológico, disponível no site do Cesop (<cesop.unicamp.br>), na página do artigo, em Arquivos Complementares.

27 Quanto maior for $\phi$, mais parecida é a distribuição binomial negativa com uma distribuição de Poisson.

28 Para o modelo foi utilizado o pacote rstanarm da linguagem $R$. 
De cima para baixo, estão respectivamente apresentadas as variáveis referentes aos deputados federais, à legenda partidária e às UFs. Sobre o primeiro nível, verifica-se que, com exceção da $51^{\text {a }}$ legislatura, o $\log$ do percentual de votos recebidos tem efeito positivo sobre a quantidade de discursos proferida pelos deputados federais. Em relação ao número de legislaturas das quais o deputado federal participou antes da que foi analisada, somente na $52^{a}$ legislatura seu efeito não é de todo positivo. Ainda nesse nível, verifica-se que ser mulher não interfere na quantidade de discursos proferidos em qualquer uma das legislaturas analisadas.

Quanto à legenda partidária, verifica-se que há um efeito positivo da classificação ideológica sobre a quantidade de discursos proferidos, com exceção da $52^{a}$ legislatura. 0 mesmo não pode ser concluído a respeito da participação da legenda partidária pela qual o deputado federal foi eleito na coalizão que compôs o governo ao longo da legislatura analisada. Somente na $51^{\text {a }}$ legislatura essa variável não apresenta efeito nulo. No caso, compor o governo apresenta efeito negativo sobre a quantidade de discursos realizada pelo parlamentar que foi eleito pela legenda.

Por sua vez, em relação à UF, a variável PIB per capita não apresenta qualquer efeito sobre a quantidade de discursos proferida pelos parlamentares ao longo de todas as legislaturas analisadas.

Tais resultados preenchem uma lacuna no conhecimento produzido a respeito da atividade parlamentar no âmbito da Câmara dos Deputados. Mesmo com conclusões que demonstram a não expressão do posicionamento ideológico dos deputados federais brasileiros através da inferência de pontos ideais a partir das votações nominais (Zucco Jr., 2009; Zucco Jr. e Lauderdale, 2011), é possível concluir que a frequência de falas proferidas no Pequeno Expediente sofre grande influência do posicionamento ideológico da legenda partidária pela qual o deputado federal foi eleito. Com exceção da $52^{a}$ legislatura, sobre todas as demais pode-se afirmar com $95 \%$ de credibilidade que há correlação entre a eleição por um partido de esquerda e a maior a frequência de discursos no Pequeno Expediente.

Verificar esse resultado antes e depois da mudança no comando do Poder Executivo federal permite supor que os parlamentares filiados a legendas de esquerda não abandonam sua estratégia de comunicação mesmo quando passam a ser governo. Por sua vez, a relação governo-oposição praticamente não surte efeito sobre o total de pronunciamentos realizados por um parlamentar. Passível de maior investigação, o efeito negativo identificado na legislatura 51 pode estar vinculado ao aspecto ideológico do governo vigente, uma vez que este não era composto pelos partidos de esquerda. Tal fato reforça ainda mais o resultado de que a ideologia tem papel fundamental sobre o uso da infraestrutura disponível para comunicação na Câmara dos Deputados.

Além disso, os efeitos positivos identificados na maior parte das legislaturas mostram que a senioridade, medida através do número de legislaturas das quais o parlamentar já participou, e a popularidade, medida pelo percentual de votos recebidos, 
têm papel relevante na estratégia de comunicação do representante. Desse modo, assim como a ciência política brasileira já faz para temas específicos, há evidências suficientes para que futuros estudos sobre representação política foquem na análise do conteúdo dos discursos parlamentares pronunciados em âmbito institucional.

\section{Conclusão}

Mesmo sem o propósito de explicar em termos causais o comportamento dos parlamentares brasileiros (Gelman, 2003, 2004, 2007, 2011), o artigo mostra que a atividade parlamentar no âmbito da $C D$ vai além da votação e da apresentação de projetos de lei. O deputado federal possui tempo, espaço, recursos e infraestrutura dedicados à comunicação política que não se restringem aos projetos em pauta. A esse respeito, ao menos seis conclusões foram identificadas

Em primeiro lugar, a disponibilidade de momentos institucionais de comunicação política é amplamente presente na atividade parlamentar no âmbito da CD. Em segundo lugar, foi identificado que tal uso varia de acordo com as regras que regulam esses momentos, seja por sua restrição temática, por sua restrição temporal ou pelo processo de escolha do orador.

Em terceiro, analisando os dados de cada um desses momentos de fala, foi possível constatar que o Pequeno Expediente é, por excelência, o principal canal de comunicação parlamentar na $C D$. Em função de possuir regras pouco restritivas, os deputados federais brasileiros o utilizam como veículo de divulgação de suas atividades e posicionamentos.

Em quarto lugar, foi constatado que o uso da infraestrutura de comunicação do Pequeno Expediente varia entre os deputados federais. Porém, não foram identificados indícios de que o aproveitamento da infraestrutura disponível poderia estar atrelado aos padrões que regem outras dimensões da atividade legislativa, como o voto nominal e a elaboração do conteúdo legislativo.

Em quinto, verificou-se que a principal variável que orienta a atividade parlamentar ao proferir o voto nominal ou a interferir no conteúdo do texto legislativo encaminhado para aprovação da presidência da República, a relação governo-oposição, não possui efeito positivo sobre o uso da infraestrutura de comunicação disponível no Pequeno Expediente. Ademais, na $51^{\text {a }}$ legislatura seu efeito foi negativo, reduzindo a probabilidade de um deputado federal, cuja legenda compõe o governo, discursar.

Por fim, em sexto lugar, há indícios consistentes de que variáveis pouco relevantes na atividade parlamentar que se desenvolve sob o processo decisório têm efeito positivo sobre o uso da tribuna enquanto meio de comunicação. As evidências de que a ideologia, a senioridade e a popularidade surtem efeito sobre a atividade de comunicação parlamentar abrem um amplo leque de investigação sobre o modo como se configura a atividade e a representação política no país. 
Ao preencher uma lacuna no conhecimento produzido a respeito da atividade parlamentar no âmbito da $C D$, convém enunciar três questões que podem orientar essa profícua agenda de pesquisa. Em primeiro lugar, do que tratam os parlamentares ao fazer uso da tribuna nos cinco minutos que Ihes são garantidos no Pequeno Expediente? Em segundo, os deputados federais se distinguem a respeito dos temas que tratam ao discursar? Por fim, as variáveis que influenciam o aproveitamento da infraestrutura de comunicação disponível no Pequeno Expediente e que se apresentam relevantes na atuação parlamentar sob o processo decisório têm importância sobre o conteúdo que é proferido?

\section{Referências bibliográficas}

ABRANChes, S. H. "Presidencialismo de coalizão: o dilema institucional brasileiro". Dados, no 31, p. 5$34,1988$.

AMES, B. "Electoral rules, constituency pressures, and pork barrel: bases of voting in the Brazilian Congress". The Journal of Politics, vol. 57, n² 2, p. 324-343, 1995a.

. "Electoral strategy under open-list proportional representation". American Journal of Political Science, vol. 39, no 2, p. 406-433, 1995b.

AMES, B. The deadlock of democracy in Brazil. Ann Arbor: University of Michigan Press, 2002.

ANSOLABEHERE, S.; JONES, P. E. "Constituents' responses to congressional roll-call voting". American Journal of Political Science, vol. 54, no 3, p. 583-597, jul. 2010.

ANTUNES, D. C. "Tolerance and democracy today: discourse of deputies in defense of conservative position". Psicologia \& Sociedade, vol. 28, n 1, p. 3-13, abr. 2016.

ARISTóteles. Retórica. São Paulo: Martins Fontes, 2012.

ARNOLD, R. D. The logic of congressional action. New Haven, CT: Yale University Press, 1990.

ARRETCHE, M. "The veto power of sub-national governments in Brazil: political institutions and parliamentary behavior in the post-1988 period". Brazilian Political Science Review (online), vol. 2, dez. 2007.

BARON, D. P. "Electoral competition with informed and uniformed voters". The American Political Science Review, vol. 88, no 1, p. 33-47, mar. 1994.

BonicA, A. "Mapping the ideological marketplace". American Journal of Political Science, vol. 58, no 2, p. 367-386, abr. 2014.

CAIN, B.; FEREJOHN, J.; FioRInA, M. The personal vote: constituency service and electoral independence. Cambridge, MA: Harvard University Press, 1990.

Clinton, J.; JACKMAn, S.; Rivers, D. "The statistical analysis of roll call data". American Political Science Review, vol. 98, no 2, p. 355-370, 2004.

Cox, G. W.; McCuBbins, M. D. Legislative leviathan: party government in the House. $2^{a}$ ed. Cambridge; New York: Cambridge University Press, 2007. 
Downs, A. An economic theory of democracy. New York: Harper; Row, 1957.

FenNo, R. Home style: House members in their districts. New York: Pearson, 1973.

Figueiredo, A.; Limongi, F. Executivo e Legislativo na nova ordem constitucional. Rio de Janeiro: Fundação Getúlio Vargas, 1999.

2002. . "Electoral incentives, parties, and budget policy". Dados, vol. 45, no 2, p. 303-344, jan.

Figueiredo, A.; Limongi, F. Poder de agenda e políticas substantivas. In: InAcio, M.; RenNó, L. (eds.). Legislativo brasileiro em perspectiva comparada. Belo Horizonte: Editora UFMG, 2010.

FIORINA, M. P. Congress: keystone of the Washington establishment. $2^{a}$ ed. New Haven: Yale University Press, 1977.

Foucault, M. A ordem do discurso. São Paulo: Loyola, 2005.

FREITAS, R. "Poder de agenda e participação legislativa no presidencialismo de coalizão brasileiro". Dissertação de Mestrado em Ciência Política. Universidade de São Paulo, São Paulo, 2010.

FreitAs, A. M. O presidencialismo da coalizão. São Paulo: Universidade de São Paulo, jul. 2013.

GeLmAN, A. "A bayesian formulation of exploratory data analysis and goodness-of-fit testing". International Statistical Review, vol. 71, no 2, p. 369-382, ago. 2003.

. "Exploratory data analysis for complex models". Journal of Computational and Graphical Statistics, vol. 13, no 4, p. 755-779, dez. 2004.

. "Rich state, poor State, red State, blue State: what's the matter with Connecticut?" Quarterly Journal of Political Science, vol. 2, no 4, p. 345-367, nov. 2007. 966, 2011.

. "Causality and statistical learning". American Journal of Sociology, vol. 117, no 3, p. 955-

GeLmAN, A.; HiLL, J. Data analysis using regression and multilevel/hierarchical models. Cambridge; New York: Cambridge University Press, 2006.

Grimmer, J. "A bayesian hierarchical topic model for political texts: measuring expressed agendas in Senate press releases". Political Analysis, vol. 18, no 1, p. 1-35, dez. 2010.

Representational style in Congress: what legislators say and why it matters. New York, NY: Cambridge University Press, 2013.

Grimmer, J.; WeStWoOd, S. J.; Messing, S. The impression of influence: legislator communication, representation, and democratic accountability. Princeton, NJ: Princeton University Press, 2014.

Grossman, G. M.; Helpman, E. "Electoral competition and special interest politics". The Review of Economic Studies, vol. 63, no 2, p. 265-286, abr. 1996.

IZUMI, M. "Os determinantes do comportamento parlamentar no Senado brasileiro (1989-2010)". Dissertação de Mestrado em Ciência Política. Universidade de São Paulo, São Paulo, 2013.

JACOBSON, G. C. "Strategic politicians and the dynamics of U.S. House elections, 1946-86". The American Political Science Review, vol. 83, no 3, p. 773-793, 1989.

KREHBIEL, K. Information and legislative organization. Ann Arbor: University of Michigan Press, 1992. 
LEONI, E. "Ideologia, democracia e comportamento parlamentar: a Câmara dos Deputados (19911998)". Dados, vol. 45, no 3, p. 361-386, 2002.

Limongi, F.; FigueIRedo, A. "Institutional foundations of coalition presidentialism". Lua Nova: Revista de Cultura e Política, no 44, p. 81-106, jan. 1998.

"The budget process and Legislative behavior: individual amendments, support for the Executive branch, and government programs". Dados, vol. 48, no 4, p. 737-776, dez. 2005.

LOHMANN, S. "An information rationale for the power of special interests". The American Political Science Review, vol. 92, no 4, p. 809-827, dez. 1998.

"Representative government and special interest politics (we have met the enemy and he is us)". Journal of Theoretical Politics, vol. 15, no 3, p. 299-319, jul. 2003.

MAINWARING, S. "Políticos, partidos e sistemas eleitorais". Novos Estudos Cebrap, vol. 29, p. 34-58, 1991.

MAINWARING, S. Rethinking party systems in the third wave of democratization: the case of Brazil. Stanford: Stanford University Press, 1999.

MANIN, B. The principles of representative government. New York: Cambridge University Press, 1997.

MAYHEW, D. R. Congress: the electoral connection. New Haven and London: Yale University Press, 1974.

Medeiros, D.; Freitas, A.; IzUmi, M. Coalizões e comportamento legislativo no Brasil (1988-2010). Trabalho preparado para apresentação no III Seminário Discente da Pós-Graduação em Ciência Política da USP, 2013.

Miguel, L. F.; FeitosA, F. "O gênero do discurso parlamentar: mulheres e homens na tribuna da Câmara dos Deputados". Dados, vol. 52, no 1, p. 201-221, mar. 2009.

MoREIRA, D. C. "Benefícios tributários federais e conexão eleitoral: a concessão de benefícios referentes ao PIS, à Cofins e à CSLL". Dissertação de Mestrado em Ciência Política. Universidade de São Paulo, São Paulo, 2011.

OLSON, M. The logic of collective action: public goods and the theory of groups, second printing with new preface and appendix. Cambridge: Harvard University Press, 1971.

Pereira, C.; Mueller, B. "A theory of executive preponderance: the committee system in the Brazilian Congress". Revista Brasileira de Ciências Sociais, vol. 15, no 43, p. 45-67, jun. 2000.

"Strategic behavior in a coalition-based presidential system: executive-legislative relations in the budgetary process in Brazil". Dados, vol. 45, no 2, p. 265-301, jan. 2002.

"Weak parties in the electoral arena, strong parties in the legislative arena: the electoral connection in Brazil". Dados, vol. 46, no 4, p. 735-771, jan. 2003.

Poole, K. T.; Rosenthal, H. "Patterns of congressional voting". American Journal of Political Science, vol. 35, no 1, p. 228-278, fev. 1991.

POTTERS, J.; SLOOF, R. "Interest groups: a survey of empirical models that try to assess their influence". European Journal of Political Economy, vol. 12, no 3, p. 403-442, 1996.

Power, T. J.; ZUCCo JR., C. "Estimating ideology of Brazilian legislative parties, 1990-2005: a research communication". Latin American Research Review, vol. 44, no 1, p. 218-246, 2009. 
REHER, R. N. "Reputação em tela: construção da reputação política por meio das televisões legislativas subnacionais". Tese de Doutorado em Ciência Política. Universidade Federal de Minas Gerais. Disponível em: <http://www.bibliotecadigital.ufmg.br/dspace/handle/1843/BUOS-AU7K2B>. 2012. Acesso em: 13 ago. 2019.

RIccI, P. "The content of Brazilian legislative output: national laws or pork barrel politics?". Dados, vol. 46, no 4, p. 699-734, jan. 2003.

. "De onde vem nossas leis? Origem e conteúdo da legislação em perspectiva comparada". Tese de Doutorado em Ciência Política. Universidade de São Paulo, São Paulo, 2006.

Shepsle, K. A.; Weingast, B. R. (eds.). Positive theories of congressional institutions. Ann Arbor: University of Michigan Press, 1995.

SмIтH, R. A. "Interest group influence in the U. S. Congress". Legislative Studies Quarterly, vol. 20, n० 1, p. 89-139, fev. 1995.

Tarouco, G. S.; Madeira, R. M. "Partidos, programas e o debate sobre esquerda e direita no Brasil". Revista de Sociologia e Política, vol. 21, no 45, p. 149-165, mar. 2013.

Vilela, E.; Neiva, P. "Themes and regions in the foreign policy of Lula and Fernando Henrique: comparison of the two presidents' discourses". Revista Brasileira de Política Internacional, vol. 54, n० 2, p. 70-96, 2011.

ZUCCO JR., C. "Ideology or what? Legislative behavior in multiparty presidential settings". The Journal of Politics, vol. 71, no 3, p. 1.076-1.092, 2009.

ZUCCO JR., C.; LAUDERDALE, B. E. "Distinguishing between influences on Brazilian legislative behavior". Legislative Studies Quarterly, vol. 36, nº 3, p. 363-396, 2011.

\section{Abstract}

Do Brazilian federal deputies speak a lot? An analysis of floor speeches frequency

This paper argues that Brazilian parliamentary activity is not limited to the decision-making process. It answers the following question: is there sufficient evidence to state that parliamentary communication is governed by the government-opposition status as previous studies have concluded about the decision-making process? To answer this question, I have analyzed the frequency of speeches of over 2,000 different Brazilian deputies over a period of more than 15 years. With robust evidence of the frequency of speeches, it appears that this activity is not governed by the government-opposition relationship. The results show the influence of other variables, such as ideology, popularity, and seniority, on parliamentary performance.

Keywords: political behavior; legislative speech; parliamentary activity; Chamber of Deputies

\section{Resumen}

Karaoke de la Cámara de los Diputados: el uso del micrófono en la actividad parlamentar

El artículo presenta la tesis de que la actividad parlamentar en el ámbito de la Cámara de los Diputados no se limita al proceso decisorio. Este artículo responde a la siguiente pregunta: ¿hay indicios suficientes para afirmar que la frecuencia de comunicación parlamentar en el ámbito de la Cámara de Diputados es gobernada por la relación gobierno-oposición, así como constatado en su actuación en el proceso decisorio? Para responder a esa pregunta, se realizó el análisis de la frecuencia de discursos proferidos por más de dos mil oradores diferentes a lo largo de más de 15 años. Con evidencias robustas sobre la frecuencia de dichos discursos, se verifica que esa actividad 
no es gobernada por la relación gobierno-oposición. Los resultados presentan la influencia de otras variables sobre la actuación parlamentar.

Palabras clave: comportamiento político; discurso político; actividad parlamentar; gobiernooposición; Cámara de los Diputados

\section{Résumé}

Karaoké de la Chambre des Députés: I'usage du microphone dans l'activité parlementaire

Cet article présente la thèse selon laquelle l'activité parlementaire au sein de la Chambre des députés ne se limite pas au processus décisoire. Il répond à la question suivante: y a - $t$-il suffisamment d'indices pour affirmer que la fréquence de communication parlementaire au sein de la Chambre des députés est gouvernée par la relation gouvernement-opposition, ainsi qu'on l'a constaté lors de son action dans le processus décisoire? Pour y répondre, on a réalisé une analyse de la fréquence de discours proférés par plus de 2000 orateurs différents au cours de plus de 15 ans. Grâce à de robustes évidences sur la fréquence des discours proférés, on vérifie que cette activité n'est pas gouvernée par la relation gouvernement-opposition. Les résultats présentent l'influence d'autres variables sur l'action parlementaire.

Mots-clés: comportement politique; discours politique; activité parlementaire; gouvernementopposition; Chambre des députés

Artigo submetido à publicação em 3 de junho de 2018. Versão final aprovada em 27 de setembro de 2019.

Opinião Pública adota a licença Creative Commons CC-BY. 